\title{
'Using the Homes Energy Efficiency Database as a Research Resource for Residential Insulation Improvements'
}

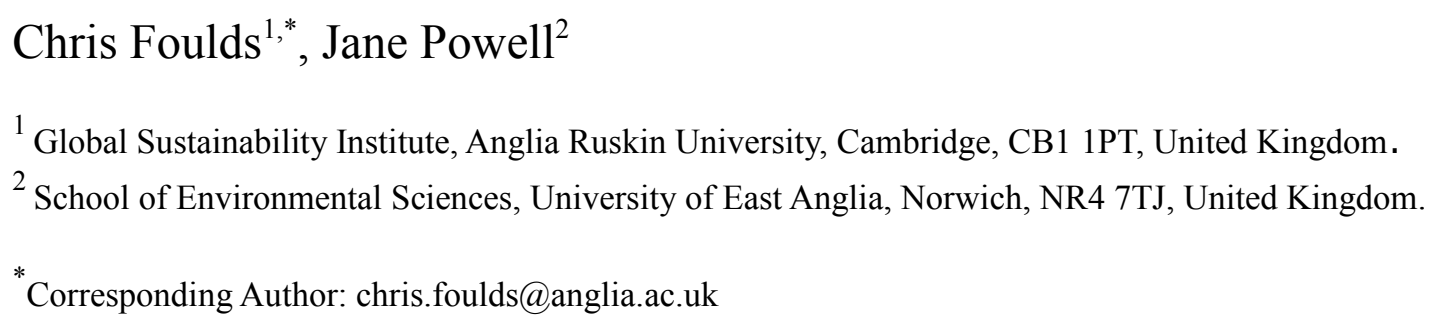

\begin{abstract}
:
In devising viable energy efficiency policies that can reduce the greenhouse gas emissions of existing dwellings (e.g. UK's Green Deal), data are required on current insulation levels and its influences. One such data source is the seldom used UK Energy Saving Trust's Homes Energy Efficiency Database (HEED), which this paper investigates using Norfolk UK local authorities as a case study. The HEED's reactive and longitudinal data collection strategies contribute to underlying biases, which is the likely reasoning for its differences with the English Housing Survey and UK 2001 Census. These differences had a cascading effect in that they manifested themselves in the indicative financial and carbon assessments undertaken. Similarly, sampling concerns also implicated correlations surrounding influences of current dwelling insulation levels. Providing one is transparent about potential biases and data concerns, the HEED can play a substantial role in guiding policy decisions and understanding dwelling stock characteristics (e.g. what makes dwellings 'Hard to Treat'). In particular, its vast (national) geographic coverage yet high resolution enables local context to be explored: a factor that this study shows to significantly shape insulation levels.
\end{abstract}

\section{Keywords:}

$\underline{\text { Retrofitting; Domestic energy consumption; English Housing Survey. }}$ 


\section{Introduction}

The UK Climate Change Act legislated for a carbon reduction target of 34\% by 2020 and 80\% by 2050 from 1990 levels (OPSI, 2008). In 2009, domestic energy consumption was responsible for approximately $40 \%$ and $25 \%$ of UK energy demand and greenhouse gas emissions respectively (DECC, 2011b). UK domestic space heating summed $64.0 \mathrm{MtCO}_{2} \mathrm{e}$ for 2009 (DECC, 2012), accounting for over 11\% of total UK emissions. Current UK dwellings are estimated to form $88 \%$ of the 2020 (CCC, 2008) and $75 \%$ of the 2050 stock (Ravetz, 2008), thus efficiency improvements to existing dwellings are essential if future carbon targets are to be achieved. Where practically possible, the UK Government intends for all lofts and cavity walls to be insulated by 2015 , with 1.8 million dwellings subjected to 'whole house' energy efficiency packages including solid wall insulation by 2020 (HM Government, 2009). In addition, "the Government anticipates all social housing with solid walls will have had SWI [solid wall insulation] installed by 2018" (ACE, 2011: 3). Domestic energy savings through insulation provision has thus become an integral feature of national energy policy.

To reduce residential emissions, the UK Government has begun to move away from placing carbon reduction obligations on energy companies, which were predominantly achieved through insulation provision (e.g. Carbon Emissions Reduction Target (CERT: 2008-12), and Energy Efficiency Commitment (EEC: 2002-08)), in favour of the Green Deal (2012 onwards). This lending framework allows the capital costs of residential energy efficiency improvements to be repaid through a post-installation energy bill charge. The Green Deals were available from autumn 2012, helping to lower the space heating load of 'Hard to Treat' (HTT) dwellings that are unable to accommodate one of the three most cost effective efficiency improvements: gas central heating, cavity wall insulation, or loft insulation. 
Information on insulation levels and the built environment is essential if policy-makers are to understand the scale of the refurbishment task and how best to achieve its challenging energy transformation targets (Skea, 2012). Previous studies have relied on national data from the English House Condition Survey and/or the Survey of English Housing for its analysis (e.g. Dresner \& Ekins, 2004; Roberts et al., 2007; Utley \& Shorrock, 2008). In 2008, the Department for Communities and Local Government (DCLG) combined the two surveys to create a new evidence base, the English Housing Survey (EHS). Using the preceding 2 years of statistically representative data collected through interview surveys ('full household sample': 17,500 per year) and property inspections ('dwelling [sub]sample': 8,000 per year), the EHS now provides a household and dwelling stock overview on an annual basis. It is the dwelling sample that is referred to in this paper. The EHS samples are drawn at random from a list of postcode address files.

An alternative data source for exploring the condition of UK dwellings is the Homes Energy Efficiency Database (HEED). There has been relatively little research on the HEED and its potential applicability as a research resource, despite scope to provide insight on the current levels of domestic insulation and improvement opportunities. To inform the allocation of scare resources, it is important that the underlying data and its assumptions are robust, transparent and geographically representative. The practical applicability of the HEED in appraising and targeting domestic insulation improvements must also be realised, in the context of these underlying constituents and biases in relation to other available data sources. The aim of this paper is to investigate these concerns, using a case study (Norfolk, UK) to specifically assess the following objectives within the core of the paper: 
1. Examine the constituents of the HEED and consider its impact on the representation of dwellings using comparisons with the EHS and Census;

2. Explore current domestic insulation levels, based on a comparison with the EHS;

3. Consider the carbon and financial implications of domestic insulation improvements;

4. Examine local socio-demographic and dwelling-specific influences on existing domestic insulation levels.

Investigating the capabilities of the HEED will also yield useful information regarding the scale of the UK low carbon retrofitting challenge, which combined with the transparent assumptions inevitably supplied by HEED data interrogations, provides a useful by-product of this paper.

This paper begins by summarising the HEED in terms of its purpose, history, constituents, and primary uses (Section 2). The above four objectives then form the foundations of the core of the paper, structuring the following methodology (Section 3) and case study results (Section 4) sections. Salient issues are explored through an overarching evaluation of the HEED (Section 5) and the paper's conclusions (Section 6), in particular relating to using the HEED in policy-making. Using the Norfolk case study as the basis for the discussion and illustration, a relatively pragmatic stance is adopted with critique of both HEED shortcomings and opportunities provided. 


\section{Context: Homes Energy Efficiency Database (HEED)}

\subsection{HEED background}

The HEED project was initiated in 2001, with data first available through the HEEDonline portal in 2005. Developed by the Energy Saving Trust (EST), on behalf of the UK Government, it records the uptake of sustainable technologies (e.g. renewables, insulation) as well as general property-related information (e.g. age, type) across UK dwellings. The HEED provides information on dwellings (both houses and flats), but no household information beyond that of tenure. The database currently has at least one item of information on 13.95 million (51\%) UK dwellings, which is considerably more than similar datasets. The HEED is a (monitoring) research resource, not a tool, since no direct policy recommendations are provided. It only offers a means (data provision) from which analysis can be conducted and actions inferred.

The UK Government used HEED data to publish CERT trends; the first in August 2011 included cavity wall and loft insulation (EST, 2012). The UK Government have also assigned the HEED as a key data source of the National Energy Efficiency Data (NEED) Framework (Skea, 2012). The purpose of the NEED is to help understand energy consumption in buildings and identify prospective energy efficiency improvements from an internal government targeting perspective, rather than an external user perspective (e.g. local authorities). Whilst data are collected and analysed on a dwelling level, this resolution is not available to HEED users. 
The HEED opportunistically compiles dwelling information from numerous sources that have collected the data for other purposes (Table 1). As a consequence of differing agendas, data source biases are a concern. The stated date for each data source are approximate; typically the installation date for energy efficiency measures and data collection date for dwellingrelated information are what constitute date ranges. Although the HEED records information on a dwelling level to avoid double counting, such information is unavailable for research due to confidentiality and data protection. The disparity in Table 1 between data items collected and the actual coverage of dwellings highlights how data have not been double counted.

Table 1 - Key HEED UK data sources (as of 01/06/2010)

\begin{tabular}{|c|c|c|c|}
\hline Data Category (Source) & $\begin{array}{l}\text { No. of Data } \\
\text { Items }\end{array}$ & $\begin{array}{c}\text { No. of } \\
\text { Dwellings }\end{array}$ & Stated Date Range \\
\hline Energy Suppliers: & & & \\
\hline Energy Supplier Data & $1,340,901$ & $1,268,869$ & Apr 2005-Mar 2008 \\
\hline EEC1 & $4,522,817$ & 595,237 & Apr 2002-Mar 2005 \\
\hline $\begin{array}{l}\text { Home Energy Check: } \\
\text { Energy Saving Trust }\end{array}$ & $50,200,436$ & $3,908,455$ & Jan 1999-Nov 2008 \\
\hline $\begin{array}{l}\text { Local Authority: } \\
\quad \text { Nottingham City Council }\end{array}$ & 48,713 & 17,519 & Oct 2000-Jan 2006 \\
\hline $\begin{array}{l}\text { Fuel Poverty Scheme: } \\
\text { Warm Front }\end{array}$ & $15,812,585^{\mathrm{b}}$ & $1,903,810^{\mathrm{b}}$ & Mar 2001-Feb 2006 \\
\hline Warm Homes & 268,255 & 26,961 & Mar 2000-Dec 2005 \\
\hline Home Energy Efficiency Scheme & 317,226 & 24,164 & Mar 2001-Mar 2006 \\
\hline Central Heating Programme & $2,339,992$ & 152,467 & Apr 2004-Jun 2005 \\
\hline Scottish Community \& Householder Renewables Initiative & 8,267 & 1,948 & Sep 1998-Dec 2001 \\
\hline $\begin{array}{l}\text { Other Sources: } \\
\quad \text { Cavity Insulation Guarantee Agency (CIGA) }\end{array}$ & $4,767,840$ & $1,453,210$ & Jan $2000-$ Oct 2008 \\
\hline Council of Registered Gas Installers (CORGI) & $22,817,900$ & $2,971,026$ & Jul 1997-Mar 2007 \\
\hline National Register of Social Housing (NROSH) & $3,081,498$ & 764,440 & Apr 2005-Mar 2007 \\
\hline Clear Skies (CSKIES) & 38,383 & 6,012 & Jan 2004-Aug 2008 \\
\hline Low Carbon Buildings Programme (LCBP) & 30,240 & 6,229 & Uploaded Apr $2008^{\mathrm{c}}$ \\
\hline Northern Ireland Sustainable Energy Database (NISED) & $5,585,012$ & 660,431 & Uploaded Mar $2010^{c}$ \\
\hline Northern Ireland Energy Efficiency Levy & 26,918 & 3,780 & Apr 2002-Oct 2008 \\
\hline Northern Ireland Housing Executive & 345,930 & 101,892 & Sep 1998-Mar 2007 \\
\hline Other & 112,175 & 85,969 & Uploaded May $2003^{\mathrm{c}}$ \\
\hline \multicolumn{4}{|c|}{$\begin{array}{l}{ }^{a} \text { Local Authority (LA) is a relatively ad-hoc data source. It comprises of initiatives that LAs have undertaken } \\
\text { and provided data to the HEED for. Currently very few LAs have such data, with Nottingham being the only LA } \\
\text { to provide sizeable information at the time of enquiry. The EST targets this data category as an area for } \\
\text { expansion. } \\
\text { b Warm Front figures are cumulative totals covering March } 2001 \text {-December 2008. However, the March } 2006 \\
\text {-December } 2008 \text { element of this had not been uploaded at the time of data collection. } \\
{ }^{\mathrm{c}} \text { Period of coverage for data was unknown. The date provided instead shows when the data were uploaded into }\end{array}$} \\
\hline
\end{tabular}


When the data for this study were collected (01/06/2010), the HEED had not been updated since December 2008. Since then HEEDonline has been updated with new data including those associated with the EEC phase 2 (April 2005-March 2008), CERT (April 2008-March 2010), Fenestration Self Assessment Scheme (January 2004-August 2008), Warm Front (March 2006-December 2008), and Energy Performance Certificates (December 2008August 2011). This was part of an upgrade to HEEDonline version 2, which also attempted to improve usability.

Element Energy (2008: 20) noted that "with the current low penetration of microgeneration, the installed base is below the statistical resolution" of both the HEED and the English House Condition Survey. Table 1's data category totals also reveal that, despite the gradual accumulation of more information, the HEED does not yet have sufficient penetration to representatively show microgeneration trends. This is noticeable given the relatively large amount of data collected on insulation and construction specifications. Perhaps this will change in the future if the EST, for instance, incorporate Feed-in-Tariff information.

Although the House of Commons Environment, Food and Rural Affairs Committee (2008) believed the HEED to be a "powerful tool for capturing and sharing data about dwelling fabric and activity to improve the energy efficiency of homes" (p. 40), it was concerned with data quality, specifically the lag time associated between data collection and integration into the HEED. DEFRA (2008) also shared these concerns, believing the lag to limit the understanding of policy performance, dwelling stock efficiency and EST endeavours. In response, the EST worked with data providers to mitigate these concerns by, for example, receiving CERT data every six months. 


\section{$2.2 \quad$ Past HEED research}

Use of the HEED in both policy and research has been minimal. For instance, Porritt et al. (2011) used the HEED to select model parameters in a heat wave dwelling adaptation study, while ESDS (2011) used it to model typical dwellings and assess the carbon implications of energy efficiency improvements. In addition, Friends of the Earth (2009) used it to quantify the number of empty residential cavity walls when estimating the potential of UK green jobs. On a practical level, LAs and EST advice centres have predominantly used the HEED to target priority areas (e.g. fuel poor) for operational, promotional and funding bid activities (EST, 2006), in addition to examining their respective areas of influence (e.g. London Borough of Lewisham, 2010). This usage could be expanded and enhanced. For example, the House of Commons Energy and Climate Change Committee (2010) highlighted that HEED data could be used to actively engage with the fuel poor nationally. Furthermore, as this paper goes onto discuss, the HEED has a potential role in helping LAs prepare for an active role in the Green Deal. The potentially significant contributions of the HEED are illustrated by the following three recent and insightful studies.

DECC (2011a) undertook an initial analysis of the NEED framework, whereby the uptake of at least one "major HEED measure", such as loft insulation, cavity wall insulation and heating measures (e.g. new boilers), was compared between a random four million representative sample (17\% of English dwellings) and population level data. The North-East had higher and London had lower insulation upgrades proportionally, relative to other English regions that all shared similar percentage trends; a finding that would not have been attainable without the HEED's extensive geographic coverage and high resolution enabling appreciation of local context. 
Hamilton et al. (2013) investigated the HEED data at the Great Britain level, assessing its representativeness in relation to English Housing Survey (EHS), Scottish House Condition Survey, and VOA's Council Tax Property Attribute data. Energy demand data were also used to investigate differences in energy consumption (as per HEED dwelling and household characteristics) and quantify energy demand changes associated with the energy efficiency interventions recorded in the HEED. On the basis of these findings, the policy implications of the HEED were discussed, with a specific emphasis on evidence-based retrofit policies and research.

Wyatt (2013) investigated the potential for a NEED framework (which the HEED forms a part of) that covers both UK domestic and commercial buildings. The study explored the dwelling and socioeconomic related drivers of domestic energy demand, as well as investigating the impact of (HEED-recorded) energy efficiency measures on energy demand. By focusing on the application of HEED data to understand changes in energy demand, Wyatt implicitly emphasises the importance of studies (including our study, and the work of DECC (2011a) and Hamilton et al., (2013)) that investigate the representativeness and underlying biases of the HEED.

These three studies provide excellent context for this paper. Indeed, a main contribution of this paper will be to add to this small body of literature and, in doing so, help provide the foundations for future research and policy that may draw upon the HEED. Specifically, this paper primarily builds on the literature's discussions regarding the representativeness of the HEED, as well as its usefulness and relevance for domestic energy policy. 


\section{Methodology}

\subsection{Data collection}

The degree of access to HEEDonline users is dependent on project specification and organisation type. In this case, academic access was restricted to a specific region on a Census Output Area (COA) resolution level, the smallest unit of analysis (approximately 125 households) available. Access to household or address level data are prohibited by the Data Protection Act and the Voluntary Agreements between the EST and data suppliers. In February 2011, the EST changed the default access level for researchers to LA level based on strict access protocols in a new data sharing agreement with data providers; thus making this study especially insightful. Data are correct as of collection date (01/06/2010).

\subsection{Objective 1 - Examine the constituents of the HEED and consider its impact on the representation of dwellings using comparisons with the EHS and Census}

The proportional split geographically and across underlying data sources was first investigated, before examining how those biases influence how HEED portrays the dwelling stock. To determine its representativeness the HEED was compared with the EHS and DCLG (2011) data, in addition to a more detailed statistical comparison with 2001 UK Census based on common factors (Tenure and Property Type: mean, 95\% confidence intervals) on a COAlevel basis $(2,846$ COAs in Norfolk). Correlation coefficients (R), dependent t-tests $(t)$, and effect size (r) calculations were used. Comparisons could not be made to (HEED-derived) national characteristics due to Norfolk-only access. 


\subsection{Objective 2 - Explore current domestic insulation levels, based on a comparison with the EHS}

The proportion of dwellings with different levels of insulation (loft, cavity, double glazing) for each Norfolk LA area were calculated using the HEED sample, and then discussed in parallel against the EHS East of England averages.

\subsection{Objective 3 - Consider the carbon and financial implications of domestic insulation improvements}

The carbon and cost implications of improving Norfolk's domestic insulation levels, using both HEED and EHS data were calculated to explore how the choice of datasets influences study outputs. To calculate the carbon and cost implications of targeted upgrades, key assumptions of specific improvement scenarios were adopted (Table 2). These calculations are intended to be indicative and, as such, ignore differences between dwelling characteristics. Prices intentionally exclude grant support, enabling the total cost to be covered by Green Deal and/or private purchases to be determined. The nature of static evaluation assumed measures could be implemented immediately. 
Table 2 - Key assumptions for domestic insulation upgrades

\begin{tabular}{|l|l|c|c|}
\hline \multirow{2}{*}{ Insulation Type } & \multicolumn{1}{|c|}{ Dwelling Improvement } & $\begin{array}{c}\text { Annual } \\
\mathbf{k W h} \\
\text { Savings }^{\text {a }}\end{array}$ & $\begin{array}{c}\text { Average } \\
\text { Capital } \\
\text { Cost (£) }\end{array}$ \\
\hline Cavity wall & Fill empty cavities (pre-1976 build assumed) & 2,150 & 380.31 \\
\hline \multirow{5}{*}{ Loft } & $\begin{array}{l}\text { Lofts }<250 \mathrm{~mm} \text { filled to 300mm; current levels of: } \\
\text { 0mm }\end{array}$ & 3304 & 250.09 \\
\cline { 2 - 4 } & $1-50 \mathrm{~mm}$ & 1464 & 237.92 \\
\cline { 2 - 4 } & $51-75 \mathrm{~mm}$ & 594 & 198.37 \\
\cline { 2 - 4 } & $76-100 \mathrm{~mm}$ & 432 & 180.72 \\
\cline { 2 - 4 } & $101-150 \mathrm{~mm}$ & 207 & 163.08 \\
\hline \multirow{2}{*}{ Windows } & $\begin{array}{l}151-200 \mathrm{~mm} \\
\text { glazing }\end{array}$ & 446 & $2,434.00$ \\
\hline External solid wall & Non-cavity walls achieve $u$-value of $0.35 \mathrm{~W} / \mathrm{m}^{2} . \mathrm{K}$ & 10,490 & 12,500 \\
\hline Internal solid wall & Non-cavity walls achieve $u$-value of $0.45 \mathrm{~W} / \mathrm{m}^{2} . \mathrm{K}$ & 9,946 & 7,000 \\
\hline
\end{tabular}

a Derived from the NEED report's actual consumption figures wherever possible (DECC, 2011a). Energy savings for external/internal solid wall insulation were derived from the UK Government's CERT assumptions (EST, 2010).

${ }^{\mathrm{b}}$ Cost of cavity, loft and glazing insulation sourced from the Building Research Establishment (Shorrock et al., 2005) and updated using the UK Consumer Price Index to December 2011 levels (ONS, 2012). The cost of external/internal solid wall insulation was taken from the UK Government's CERT assumptions (EST, 2010).

The HEED's loft insulation categories do not have the same boundaries as any available energy saving assumptions, and none are provided by the EST to accompany the data and assist with interpretation. HEED, as well as EHS, categories were therefore re-classified slightly to fit Table 2's categories.

DEFRA/DECC's carbon emission factors (Hill et al., 2011) and SAP's three year fuel cost averages (BRE, 2010) were multiplied against area-weighted primary heating fuel factors (calculated using the HEED). EHS-derived cost and carbon savings could not use COA-scale fuel type averages to limit the influence of geographic differences, with a standard gas emissions factor instead used throughout.

Two uptake scenarios were employed. The first scenario assumed $100 \%$ uptake of all insulations, on the basis of the assumptions in Table 2, except for solid wall insulation which 
had an even split between internal (50\%) and external (50\%) insulation. An alternative scenario was needed due to structural constraints. For example, loft insulation cannot be installed in dwellings with no loft (e.g. many flats) or loft access (e.g. some older buildings). A building in certain (e.g. conservation) areas and/or of a certain status may be legally prohibited from changing its appearance (e.g. replacing windows, external insulation). Further, human choice dictates the magnitude of uptake programmes and thus whether, for instance, external or internal insulation (or neither) is installed. Therefore, for the second scenario, the UK's Fourth Carbon Budget 2020 assumptions were utilised (CCC, 2010). Note that no specific assumptions regarding glazing were available and that an even externalinternal solid wall split was once again assumed:

- $90 \%$ of cavities are filled

- $90 \%$ of dwellings have $300 \mathrm{~mm}$ thick loft insulation

- $90 \%$ of single glazing replaced with low emissivity double glazing

- $12.5 \%$ of non-cavity walled dwellings have internal wall insulation

- $12.5 \%$ of non-cavity walled dwellings have external wall insulation

Actual energy savings rarely achieve theoretical estimates due to rebound effects, including comfort taking as well as modelling errors surrounding insulation performance and ventilation heat losses. Therefore a reduction factor of 52.5\%: (literature mean of 53\% (BRE, 2003), 50\% (Henderson, 2004), 67\% (Hong et al., 2006), 40\% (Martin \& Watson, 2006)) was applied to solid wall insulation estimates (the other insulation types used actual consumption data) to account for the gap between actual and predicted savings. It is acknowledged that these are broad and equally applied across insulation measures. 
Discounted payback periods were determined through the Net Present Value method, using HM Treasury's (2003) discount rates of 3.5\% per annum. The low energy price increase rate of $0.315 \%$, the mean gas/electricity price rise over April 2008-March 2010 (DECC, 2010), was adopted to provide a conservative cost estimate.

\subsection{Objective 4 - Examine local socio-demographic and dwelling-specific influences on existing domestic insulation levels}

DECC (2011a) acknowledges that since household energy consumption changes can be caused by many different influences, there is a need to incorporate socio-demographic data into future versions of the NEED framework. Therefore this paper investigates the relationship of existing insulation levels to various influences, in exploring barriers to insulation upgrades, considering 'quick win' targeting opportunities, and learning lessons from past trends.

To understand the characteristics of such relationships, Spearman's rank correlation coefficients (R) were calculated. Percentages of dwellings (relative to 2001 Census totals) in a COA with empty cavities, completely uninsulated lofts, or entirely single glazing were used. Solid wall insulation was not analysed since the HEED has no information on its existing levels. Using COA percentages, not absolute numbers, removed size-associated bias. COAs with no data were excluded from analysis.

Socio-demographic factors were sourced from the Census (e.g. qualifications, social grades) and property-related factors from the HEED (e.g. fuel costs, heating systems). Property type 
and tenure variables (both available in the HEED and Census) were correlated against the HEED-derived insulation levels as an additional HEED-Census comparison.

To test that an insulation-predictor relationship revealed by a correlation coefficient was directly attributable to a specific factor in question, multicollinearity (i.e. using the same type of information more than once) was examined by correlating factors against one another and calculating Variance Inflation Factors (VIF). A conservative threshold (VIF=5) was used, as well as the average VIF being benchmarked against anything considerably greater than one.

In order to provide an insight into changing building practices and the influence of past Government policies, individual property age bands and insulation levels were correlated against each other.

\section{Norfolk case study results}

\subsection{Objective 1 - Examine the constituents of the HEED and consider its impact on the representation of dwellings using comparisons with the EHS and Census}

The characteristics of the HEED were determined by data source (Table 3) and Norfolk's seven LA areas (Table 4). Data source contributions are not provided by the HEED, thus were calculated by filtering a data type (e.g. glazing) by a data source (e.g. energy suppliers). Data types which are not energy efficiency measures cannot be filtered by data source or indeed any other variable, meaning that the proportions of dwellings attributed to all data sources were unattainable. However, this filtering issue did not prevent the 'Total' (Table 3, column 7) coverage from being attained. 
Table 3 - Percentage of Norfolk dwellings with data, per HEED data source category. Total Norfolk dwellings 343, 135 (Census, 2001)

\begin{tabular}{|l|c|c|c|c|c|c|}
\hline \multicolumn{1}{|c|}{ Data Source } & $\begin{array}{c}\text { Energy } \\
\text { Suppliers } \\
\text { Data Type }\end{array}$ & $\begin{array}{c}\text { Home } \\
\text { Energy } \\
\text { Check }\end{array}$ & $\begin{array}{c}\text { Local } \\
\text { Authority }\end{array}$ & $\begin{array}{c}\text { Fuel } \\
\text { Poverty } \\
\text { Scheme }\end{array}$ & $\begin{array}{c}\text { Other } \\
\text { Sources }\end{array}$ & Total \\
\hline Loft Insulation & .21 & 11.05 & .00 & 2.96 & .58 & $\mathbf{1 4 . 8 1}$ \\
\hline Glazing & .00 & 11.70 & .00 & 2.71 & .00 & $\mathbf{1 4 . 4 1}$ \\
\hline External Wall Type & .32 & 10.39 & .00 & 2.79 & 7.83 & $\mathbf{2 1 . 3 3}$ \\
\hline Property Type & - & - & - & - & - & $\mathbf{1 6 . 6 8}$ \\
\hline Tenure & - & - & - & - & - & $\mathbf{1 7 . 6 3}$ \\
\hline Property Age & - & - & - & - & - & $\mathbf{1 4 . 6 7}$ \\
\hline Main Heating Fuel & - & - & - & - & - & $\mathbf{2 3 . 6 5}$ \\
\hline Main Heating System & .47 & 11.43 & .00 & 1.02 & 6.05 & $\mathbf{1 8 . 9 7}$ \\
\hline \hline \multicolumn{1}{|c|}{ Mean: } & .25 & $\mathbf{1 1 . 1 4}$ & $\mathbf{. 0 0}$ & 2.37 & 3.62 & $\mathbf{1 7 . 7 7}$ \\
\hline
\end{tabular}

Table 4 - Percentage of Norfolk dwellings with data, per local authority area. Total Norfolk dwellings 343, 135 (Census, 2001)

\begin{tabular}{|l|c|c|c|c|c|c|c|c|}
\hline \multicolumn{1}{|c|}{$\begin{array}{c}\text { Data } \\
\text { Type }\end{array}$} & $\begin{array}{c}\text { Brecklan } \\
\boldsymbol{d}\end{array}$ & $\begin{array}{c}\text { Broadlan } \\
\boldsymbol{d}\end{array}$ & $\begin{array}{c}\text { Great } \\
\text { Yarmout } \\
\boldsymbol{h}\end{array}$ & $\begin{array}{c}\text { King's } \\
\text { Lynn \& } \\
\text { West } \\
\text { Norfolk }\end{array}$ & $\begin{array}{c}\text { North } \\
\text { Norfol } \\
\boldsymbol{k}\end{array}$ & $\begin{array}{c}\text { Norwic } \\
\boldsymbol{h} \text { City }\end{array}$ & $\begin{array}{c}\text { South } \\
\text { Norfol } \\
\boldsymbol{k}\end{array}$ & $\begin{array}{c}\text { Norfolk } \\
\text { Average }\end{array}$ \\
\hline $\begin{array}{l}\text { Loft } \\
\text { insulation }\end{array}$ & 11.09 & 17.37 & 10.51 & 9.23 & 10.98 & 10.15 & 18.45 & $\mathbf{1 4 . 8 1}$ \\
\hline Glazing & 10.26 & 16.47 & 10.11 & 7.30 & 11.11 & 9.18 & 20.50 & $\mathbf{1 4 . 4 1}$ \\
\hline $\begin{array}{l}\text { External } \\
\text { wall type }\end{array}$ & 19.52 & 24.51 & 16.53 & 17.54 & 20.83 & 22.24 & 27.03 & $\mathbf{2 1 . 3 3}$ \\
\hline $\begin{array}{l}\text { Property } \\
\text { type }\end{array}$ & 13.76 & 21.27 & 16.07 & 13.73 & 14.33 & 15.05 & 23.66 & $\mathbf{1 6 . 6 8}$ \\
\hline Tenure & 16.12 & 18.89 & 19.83 & 14.29 & 16.75 & 16.96 & 22.14 & $\mathbf{1 7 . 6 3}$ \\
\hline $\begin{array}{l}\text { Property } \\
\text { age }\end{array}$ & 12.34 & 19.60 & 14.26 & 11.01 & 14.54 & 12.21 & 22.22 & $\mathbf{1 4 . 6 7}$ \\
\hline $\begin{array}{l}\text { Main } \\
\text { heating } \\
\text { fuel }\end{array}$ & 20.07 & 28.40 & 23.06 & 19.64 & 20.92 & 25.75 & 28.42 & $\mathbf{2 3 . 6 5}$ \\
\hline $\begin{array}{l}\text { Main } \\
\text { heating } \\
\text { system }\end{array}$ & 15.63 & 23.00 & 18.87 & 14.54 & 17.05 & 19.35 & 24.42 & $\mathbf{1 8 . 9 7}$ \\
\hline \hline \multicolumn{1}{|c|}{ Mean: } & $\mathbf{1 4 . 8 5}$ & $\mathbf{2 1 . 1 9}$ & $\mathbf{1 6 . 1 6}$ & $\mathbf{1 3 . 4 1}$ & $\mathbf{1 5 . 5 6}$ & $\mathbf{1 6 . 3 6}$ & $\mathbf{2 3 . 4 3}$ & $\mathbf{1 7 . 7 7}$ \\
\hline
\end{tabular}

The considerable variation between energy efficiency measure(s) (Tables 3 and 4) is supported by initial analysis of the NEED framework (DECC, 2011a). Despite such variability, householders installing loft and/or cavity insulation consistently dominated (over $30 \%$ ) the HEED records of energy efficiency upgrades. Since this analysis does not use dwelling-level data, individual dwellings may overlap Table 4's categories (e.g. which households upgraded one or both loft and cavity insulation). Nevertheless it is interesting to 
see that loft insulation is no more dominant than glazing, which DECC (2011a) barely mentions.

Each insulation type covers $\sim 14 \%$ of Norfolk dwellings from the main three sources (Energy Suppliers, EST's Home Energy Check (HEC), Fuel Poverty schemes). Note 'Other Sources', which adds a further $\sim 8 \%$ coverage to the external wall type variable, can be wholly attributed to the Cavity Insulation Guarantee Agency (CIGA). CIGA only collects data when issuing a guarantee (i.e. post-installation). The Energy Supplier and Fuel Poverty data also reveals that the dwellings it represents are all insulated to current building regulations.

The dwelling sample of the EHS, which UK policy relies upon, covers $0.04 \%(8,000)$ of dwellings nationally, whereas the mean sample size of the HEED insulation types in Norfolk was $16.85 \%(64,624)$. Although the HEED offers a larger sample size, its sampling strategy is unsystematic and lacks rigour. Therefore the EHS statistically representative sample provides a good benchmark for comparison (Appendix 9.1), particularly because the unclustered sampling approach of the EHS at the LA level makes it nationally and regionally representative (DCLG, 2013). However, the different ways of categorising each property variable does make the HEED and EHS relatively incomparable. For instance, the HEED has very different dwelling age boundaries to the EHS, although on the surface both seem fairly similar: assuming equal building rates within age bands, the mean annual difference (relative to 2010 total stock) was $\pm 3.07 \%$ (range: $\pm 6.74 \%$ and $\pm 0.01 \%$ ).

Despite the HEED and EHS categorising property type, tenure, and main heating fuel (e.g. gas, electricity, oil) variables very similarly, there is no way to know with any certainty which is correct. The differences could be due to local context rather than the potential sampling 
biases associated with the HEED. Comparing the EHS' smallest unit of analysis (East of England region) against HEED data in isolation is not particularly helpful here because the largest unit of analysis using the HEED data available to this study is the County (Norfolk) level, as well as the EHS only being designed to represent England and its regions (not anything geographically smaller). The EHS can thus highlight broad regionally dominant trends, such as similar proportions of electric storage heaters $(\sim 7 \%)$ that substitute central heating systems in 'off gas' areas; whereas more local characteristics can be missed, as demonstrated by the EHS not grasping Norfolk's rural features. For instance there are proportionally over 2.5 times more dwellings in Norfolk that use oil as a main heating fuel (as per HEED), relative to the East of England (5.44\%) (as per EHS). Indeed the HEED provides more detailed evidence, allowing one to identify that $20-25 \%$ of dwellings in Breckland, North Norfolk and South Norfolk LA areas predominantly use oil. The EHS could never capture such local context, because it is designed to target representativeness at the regional level and above - thus comparisons below this scale (e.g. LAs) will inevitably be subject to problems.

Other datasets must thus be sought to compare the HEED at the local level, hence its tenure data were compared against the DCLG (2011) LA-level equivalents (Table 5). These are still not ideal benchmarks because of their overt focus on social renters (a product of LA data collection intentions), with private sector tenures only calculated as the residual stock after removing LA, HA and other public sector values. Nevertheless, the comparison (Table 5) does support earlier parallels with EHS which indicated the HEED underrepresents social renters (EHS in the East: $15.75 \%$; HEED in Norfolk: 3.55\%). By showing some LA areas to have LA rented dwellings, when in recent years they have been transferred to Housing Associations, Table 5 also emphasises the dated nature of elements of the HEED. 
Table 5 - Comparing percentage of dwelling stock across tenures, using DCLG (2011) against HEED [in italicised brackets] Norfolk's LA area data

\begin{tabular}{|c|c|c|c|c|c|c|c|c|}
\hline Tenure & $\begin{array}{c}\text { Brecklan } \\
d\end{array}$ & $\begin{array}{c}\text { Broadlan } \\
\quad d\end{array}$ & $\begin{array}{c}\text { Great } \\
\text { Yarmout } \\
h\end{array}$ & $\begin{array}{c}\text { King's } \\
\text { Lynn } \\
\text { \& West } \\
\text { Norfol } \\
k\end{array}$ & $\begin{array}{c}\text { North } \\
\text { Norfol } \\
\quad k\end{array}$ & $\begin{array}{c}\text { Norwic } \\
\text { h City }\end{array}$ & $\begin{array}{c}\text { South } \\
\text { Norfol } \\
k\end{array}$ & $\begin{array}{c}\text { Norfolk } \\
\text { Averag } \\
e\end{array}$ \\
\hline $\begin{array}{l}\text { Owner Occupied \& } \\
\text { Privately Rented }\end{array}$ & $\begin{array}{r}85.8 \\
(97.19) \\
\end{array}$ & $\begin{array}{c}91.0 \\
(99.07) \\
\end{array}$ & $\begin{array}{r}82.6 \\
(88.84) \\
\end{array}$ & $\begin{array}{r}85.6 \\
(88.84) \\
\end{array}$ & $\begin{array}{c}88.0 \\
(97.87) \\
\end{array}$ & $\begin{array}{r}67.3 \\
(91.81) \\
\end{array}$ & $\begin{array}{c}88.4 \\
(97.66) \\
\end{array}$ & $\begin{array}{c}84.1 \\
(95.41) \\
\end{array}$ \\
\hline LA Rented & $\begin{array}{c}0 \\
(0.15) \\
\end{array}$ & $\begin{array}{c}0 \\
(0.15) \\
\end{array}$ & $\begin{array}{c}13.7 \\
(5.24) \\
\end{array}$ & $\begin{array}{c}0 \\
(5.24) \\
\end{array}$ & $\begin{array}{c}0 \\
(0.54) \\
\end{array}$ & $\begin{array}{c}24.9 \\
(5.15) \\
\end{array}$ & $\begin{array}{c}0 \\
(0.35) \\
\end{array}$ & $\begin{array}{c}5.5 \\
(1.96)\end{array}$ \\
\hline HA Rented & $\begin{array}{c}13.6 \\
(1.62) \\
\end{array}$ & $\begin{array}{c}8.8 \\
(0.63) \\
\end{array}$ & $\begin{array}{c}3.6 \\
(1.44) \\
\end{array}$ & $\begin{array}{c}13.4 \\
(1.44) \\
\end{array}$ & $\begin{array}{l}12.0 \\
(1.35) \\
\end{array}$ & $\begin{array}{c}7.7 \\
(2.14) \\
\end{array}$ & $\begin{array}{l}11.5 \\
(1.70) \\
\end{array}$ & $\begin{array}{c}10.1 \\
(1.59) \\
\end{array}$ \\
\hline Other $^{\mathrm{a}}$ & $\begin{array}{c}0.6 \\
(1.05) \\
\end{array}$ & $\begin{array}{c}0.3 \\
(0.15) \\
\end{array}$ & $\begin{array}{c}0 \\
(4.47) \\
\end{array}$ & $\begin{array}{c}1.1 \\
(4.70) \\
\end{array}$ & $\begin{array}{c}0 \\
(0.22) \\
\end{array}$ & $\begin{array}{c}0 \\
(0.90) \\
\end{array}$ & $\begin{array}{c}0 \\
(0.29) \\
\end{array}$ & $\begin{array}{c}0.3 \\
(1.04) \\
\end{array}$ \\
\hline
\end{tabular}

${ }^{a}$ DCLG (2011) labels this 'Other Public Sector' which includes dwellings not owned by LAs or HAs but by other public sectors bodies (e.g. National Health Service; Department of Defence; Forestry Commission), whereas HEED labelled it 'Other' dwellings.

To further investigate how representative the HEED is of the whole dwelling stock, additional comparisons were undertaken at the smallest unit of analysis possible between the HEED and the, albeit dated, 2001 Census, using the only two common variables (Tenure; Property Type). Noteworthy differences were found between the mean (95\% confidence intervals) COA-level breakdowns of property type and tenure (Figure 1), which were reinforced by correlation, t-test, and effect size calculations (Table 6). 
Figure 1 - Mean (95\% confidence intervals) percentage make-up of Norfolk COAs by tenure and property types from HEED and Census 2001 sources $(\mathrm{N}=2,846)$.

Table 6 - Comparison of HEED and Census 2001 property data: correlation coefficients $(\mathrm{R})$, t-values $(\mathrm{t})$, and effect sizes $(\mathrm{r})(\mathrm{N}=2,846)$.

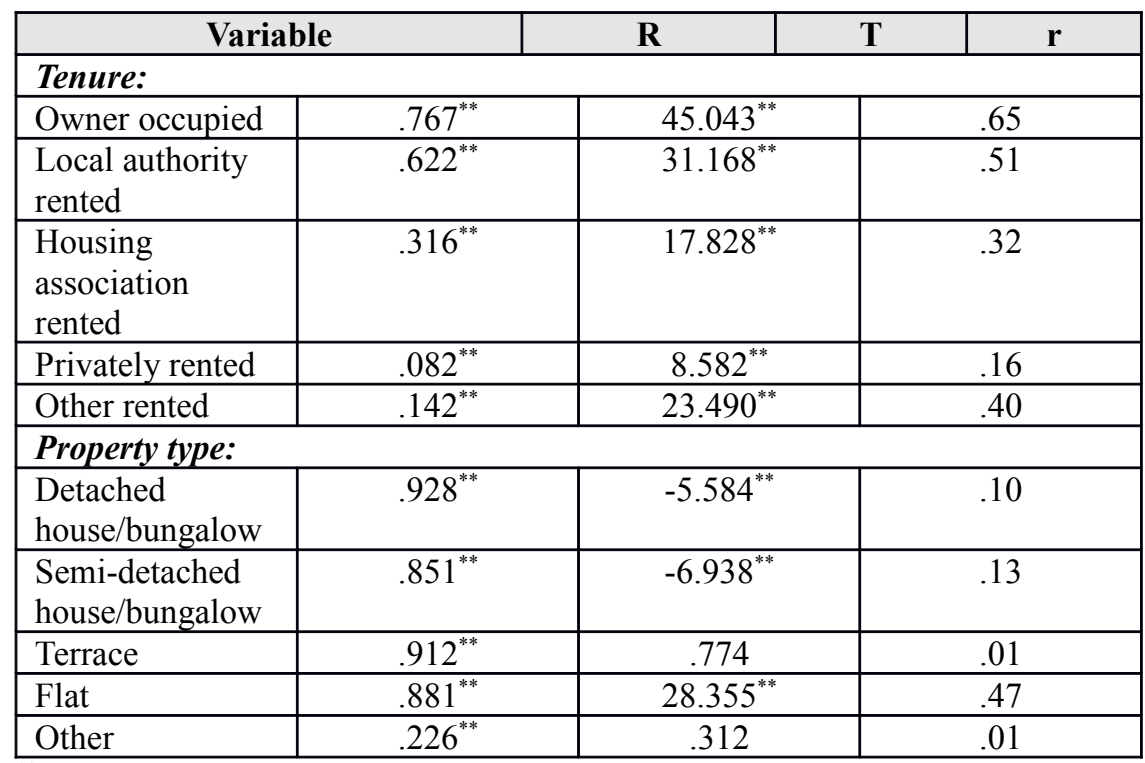

$$
p<.01
$$


The correlation coefficients suggest that the makeup of Norfolk's residential tenures and property types are similar from the HEED and Census perspectives, supporting the findings of Hamilton et al. (2013) that showed the HEED to be largely representative of the national housing stock. Yet deeper (t-test) analysis indicates fundamental differences as all comparisons showed significant differences $(\mathrm{p}<.01)$ excluding terrace $(\mathrm{p}=.561)$ and other $(\mathrm{p}=.245)$ dwellings. It is inevitable that a resource that accumulates different dwelling snapshots will differ to a static (Census) assessment. However such differences could be due to the 2001 Census being incorrect as of now (e.g. a surge in buying dwellings occurred over the last decade, thereby altering the relative tenure percentages), or vice versa, begging comparisons with the forthcoming 2011 Census. Property type is less changeable than dwelling tenure, perhaps making its HEED-Census comparisons less affected by the Census data's age. The greater changeability of tenure is reflected by its consistently higher t-values (Table 6) which represent the size of the difference between the two compared means, independent of original units.

By relying on data that are collected opportunistically and, in particular, upon completion of energy efficiency upgrades (as Hamilton et al. (2013) also reveal to be true at the national level), the HEED has an unrepresentatively high proportion of owner occupiers $(11.98 \%$ higher than the Census), who have more of a monetary incentive to invest and improve their dwelling. The emphasis on owner occupied dwellings is likely to have contributed to the HEED's relative underrepresentation of flats, as there is a higher proportion that are rented (DCLG, 2010a). Indeed not only does Figure 1 show the Census to have more flats than the HEED, but the noticeable variation (demonstrated by a large $95 \% \mathrm{CI}$ ) in the Census' flats data is not mirrored by the HEED. Such differences are reinforced by the flats' high t-value, relative to other property type variables. Conservative carbon and cost assessments are 
therefore likely when using HEED data due to flats (excluding converted flats) having a lower average energy efficiency (Standard Assessment Procedure) rating and thus higher annual carbon emissions than other property types (DCLG, 2010b).

According to effect size calculations (Table 6), the impact on study accuracy of applying HEED data was shown to vary. Assuming the Census is representative of the current population, both owner occupied and LA rented dwellings have a large effect on study accuracy ( $\mathrm{r} \geq 0.5$ : explaining $\geq 25 \%$ of total variance). HA and other rented tenures were shown to have a medium effect ( $r \geq 0.3$ : explaining $\geq 9 \%$ of total variance), as was Flats which comfortably had the greatest 'effect' of the property type variables. All other HEED variables have at least a small effect ( $\mathrm{r} \geq 0.1$ : explaining $\geq 1 \%$ of total variance), excluding the 'ineffective' terrace and other property types which the HEED attributes to $17.64 \%$ of Norfolk's stock.

Relatively few of the 2,846 COAs had no HEED data available for the variables: loft insulation (11), glazing (8), external wall type (4), property type (3), tenure (3), and property age (4). Only one COA (33UBHS0007) had no data available across all variables.

\subsection{Objective 2 - Explore current domestic insulation levels, based on a comparison with the EHS}

Through examination of current dwelling insulation levels (Tables 7-9) additional comparisons were made between the HEED and the EHS. Such overview exercises are of vital importance in understanding the scale of the retrofitting challenge ahead. HEED-derived 
averages are provided here at the LA level to get a better indication of how (and indeed whether) it represents local context. 
Table 7 - Proportion of existing dwellings with different loft insulation thicknesses: HEED and EHS insights

\begin{tabular}{|c|c|c|c|c|c|c|c|c|c|}
\hline \multirow{2}{*}{$\begin{array}{c}\text { Loft } \\
\text { insulation } \\
\text { thickness } \\
(\mathbf{m m})\end{array}$} & \multicolumn{8}{|c|}{ HEED } & \multirow{2}{*}{$\begin{array}{c}\text { EHS } \\
\text { East of } \\
\text { England } \\
\text { Average } \\
\end{array}$} \\
\hline & $\begin{array}{c}\text { Brecklan } \\
d\end{array}$ & $\begin{array}{c}\text { Broadlan } \\
\quad d\end{array}$ & $\begin{array}{c}\text { Great } \\
\text { Yarmout } \\
h\end{array}$ & $\begin{array}{c}\text { King's } \\
\text { Lynn } \\
\text { \& West } \\
\text { Norfol } \\
\text { k }\end{array}$ & $\begin{array}{c}\text { North } \\
\text { Norfol } \\
\quad k\end{array}$ & $\begin{array}{c}\text { Norwic } \\
\boldsymbol{h} \text { City }\end{array}$ & $\begin{array}{c}\text { South } \\
\text { Norfol } \\
\quad k\end{array}$ & $\begin{array}{c}\text { Norfolk } \\
\text { Averag } \\
e\end{array}$ & \\
\hline 0 & 3.49 & 2.93 & 8.63 & 3.72 & 5.44 & 7.01 & 3.90 & 4.68 & 4.44 \\
\hline $1-24$ & 0.49 & 0.21 & 0.33 & 0.64 & 0.34 & 0.52 & 0.35 & 0.40 & \multirow{2}{*}{4.38} \\
\hline $25-49$ & 1.54 & 1.29 & 2.13 & 2.01 & 1.15 & 1.89 & 0.91 & 1.48 & \\
\hline $50-74$ & 13.25 & 15.93 & 11.07 & 8.81 & 13.88 & 12.20 & 15.45 & 13.36 & \multirow{2}{*}{19.21} \\
\hline $75-99$ & 2.78 & 4.99 & 7.02 & 6.14 & 4.09 & 5.60 & 2.27 & 4.48 & \\
\hline $100-149$ & 22.82 & 26.30 & 19.73 & 21.61 & 23.69 & 20.63 & 25.18 & 23.33 & 29.17 \\
\hline 150-199 & 17.11 & 19.88 & 16.07 & 16.33 & 20.90 & 15.69 & 20.69 & 18.42 & 12.06 \\
\hline $200-249$ & 7.52 & 6.27 & 7.11 & 8.31 & 7.7 & 6.28 & 9.11 & 7.52 & \multirow{2}{*}{30.73} \\
\hline More than 250 & 31.01 & 22.20 & 27.92 & 32.42 & 22.76 & 30.18 & 22.15 & 26.32 & \\
\hline
\end{tabular}

Table 8 - Proportion of existing dwellings with different external wall type: HEED and EHS insights

\begin{tabular}{|c|c|c|c|c|c|c|c|c|c|}
\hline \multirow[b]{2}{*}{ External wall type } & \multicolumn{8}{|c|}{ HEED } & \multirow{2}{*}{$\begin{array}{c}\text { EHS } \\
\text { East of } \\
\text { England } \\
\text { Average } \\
\end{array}$} \\
\hline & $\begin{array}{c}\text { Brecklan } \\
d\end{array}$ & $\begin{array}{c}\text { Broadlan } \\
d\end{array}$ & $\begin{array}{c}\text { Great } \\
\text { Yarmout } \\
h\end{array}$ & $\begin{array}{c}\text { King's } \\
\text { Lynn } \\
\text { \& West } \\
\text { Norfol } \\
k\end{array}$ & $\begin{array}{c}\text { North } \\
\text { Norfol } \\
\quad k\end{array}$ & $\begin{array}{c}\text { Norwic } \\
h \text { City }\end{array}$ & $\begin{array}{c}\text { South } \\
\text { Norfol } \\
\boldsymbol{k}\end{array}$ & $\begin{array}{c}\text { Norfolk } \\
\text { Averag } \\
e\end{array}$ & \\
\hline Filled cavity & 69.02 & 63.58 & 51.76 & 69.92 & 64.22 & 69.22 & 58.60 & 64.38 & 39.16 \\
\hline Unfilled cavity & 8.24 & 12.21 & 7.67 & 8.68 & 8.70 & 6.32 & 10.44 & 9.01 & 33.91 \\
\hline Solid & 14.93 & 19.62 & 35.84 & 15.08 & 17.45 & 20.99 & 20.87 & 19.92 & \multirow{4}{*}{26.93} \\
\hline Stone & 1.16 & 0.88 & 0.70 & 2.27 & 3.93 & 0.80 & 1.00 & 1.51 & \\
\hline Timber framed & 1.42 & 0.77 & 0.97 & 1.08 & 0.88 & 0.56 & 2.90 & 1.26 & \\
\hline Other construction & 5.23 & 2.95 & 3.05 & 2.97 & 4.82 & 2.10 & 6.19 & 3.92 & \\
\hline
\end{tabular}

Table 9 - Proportion of existing dwellings with different extents of double glazing: HEED and EHS insights

\begin{tabular}{|c|c|c|c|c|c|c|c|c|c|}
\hline \multirow{2}{*}{$\begin{array}{c}\text { Extent } \\
\text { of } \\
\text { double } \\
\text { glazing } \\
(\%)\end{array}$} & \multicolumn{8}{|c|}{ HEED } & \multirow{2}{*}{$\begin{array}{c}\text { EHS } \\
\text { East of } \\
\text { England } \\
\text { Average } \\
\end{array}$} \\
\hline & $\begin{array}{c}\text { Brecklan } \\
d\end{array}$ & $\begin{array}{c}\text { Broadlan } \\
\quad d\end{array}$ & $\begin{array}{c}\text { Great } \\
\underset{h}{\text { Yarmout }}\end{array}$ & $\begin{array}{c}\text { King's } \\
\text { Lynn } \\
\text { \& West } \\
\text { Norfol } \\
k\end{array}$ & $\begin{array}{c}\text { North } \\
\text { Norfol } \\
\quad k\end{array}$ & $\begin{array}{c}\text { Norwic } \\
h \text { City }\end{array}$ & $\begin{array}{c}\text { South } \\
\text { Norfol } \\
\quad k\end{array}$ & $\begin{array}{c}\text { Norfolk } \\
\text { Averag } \\
e\end{array}$ & \\
\hline 0 & 8.51 & 7.03 & 16.31 & 13.28 & 12.54 & 25.35 & 8.65 & 12.11 & 7.79 \\
\hline $1-50$ & 7.06 & 7.09 & 9.25 & 10.15 & 10.56 & 11.40 & 7.89 & 8.77 & 5.14 \\
\hline 51-99 & 12.61 & 12.65 & 12.35 & 13.24 & 14.49 & 11.77 & 13.30 & 12.95 & 11.47 \\
\hline 100 & 71.82 & 73.23 & 62.09 & 63.32 & 62.41 & 51.48 & 70.16 & 66.17 & 75.61 \\
\hline
\end{tabular}


Whilst the work of Hamilton et al. (2013) found the HEED not to be statistically similar to the EHS, the HEED-Norfolk and EHS-East insulation averages are shown here to be broadly similar, particularly the spread across different loft insulation thicknesses. Both show adequate insulation levels to have already been achieved by a large proportion of dwellings. There is, however, one clear difference: the EHS assumes a relatively even split in the proportion of filled (39.16\%) and unfilled (33.91\%) cavity walls, whereas the HEED show there to be considerably more filled cavities (64.38\% vs. 9.01\%). Interestingly though the EHS and HEED do agree on the proportion attributed to the residual (non-cavity) external wall types, such as solid wall, stone or timber framed external walls.

This exercise also highlighted two other concerns. Firstly, the most disaggregated variables from the EHS, which were included in Tables 7-9 (and in Appendix 9.1), do not provide as a detailed breakdown as the HEED does. Secondly, the EHS and HEED have no category for walls that are 'partially filled', which accounts for 1.6-2.4 million dwellings in Great Britain. The EHS, and its predecessor the English House Condition Survey, classify 'partially filled' external walls as 'filled' (Iwaszkiewicz et al., 2010). As a collection of various data sources, the HEED consists of an amalgamation of different categorisation approaches thereby once again emphasising how no dataset is without its problems.

The HEED may have a tendency to show dwellings in a more efficient light because the database is dominated by those that have been improved. Indeed, Hamilton et al. (2013) revealed around $80 \%$ of homes recorded in the HEED (nationally) has had some sort of energy efficiency measure installed. For example, using Warm Front data alone showed all cavities and lofts to be insulated to current Government-targeted levels. Nevertheless the Warm Front also provided other (i.e. non-insulation) information which could help 
researchers understand the dwelling stock further (e.g. property age, type). This said, as the Warm Front accounts for $14.2 \%$ of HEED data covering $13.6 \%$ of UK dwellings (Table 1), its potentially conservative leanings must remain in the forefront of a HEED user's mind. Around $45 \%$ of HEED data (covering $28 \%$ of UK dwellings) are collected in ways that have not involved any improvements being made to the property. This is likely to be the reason for the significant disagreement between the HEED and EHS regarding the proportion of filled cavities. However, perhaps it is the cavity wall estimates that are most affected because loft insulation is relatively similar and the proportions of entirely double glazed dwellings are actually shown to be higher by the EHS than the HEED.

Relative to national trends, the HEED showed Norfolk to have $20 \%$ solid walled dwellings, as opposed to the English average of $31 \%$ (Beaumont, 2007). Past estimates suggest Wales to have the highest proportion (47\%) of solid walled dwellings in the UK (Pett, 2004), thus is a further illustration of how local context could underlie differences in the HEED-Norfolk data. Indeed, there is a significant range of insulation levels across the LA-aggregated areas, which the HEED-Norfolk and, lesser still, the EHS-East averages fail to capture. The completion of Objective 4 in Section 4.4 revisits this issue and attempts to indicate the influences behind local variations in dwelling insulation levels.

\subsection{Objective 3 - Consider the carbon and financial implications of domestic insulation improvements}

This section continues HEED-EHS comparisons by using respective insulation levels to calculate the carbon and financial implications of improving Norfolk's domestic insulation. 
As was outlined in the Methods section (3.4), a simple calculation approach was adopted to give an indicative feel to what basing such analyses on different data types could lead to. 


\subsubsection{Carbon implications}

The main focus of this section is the maximum potential (i.e. full uptake) of insulation measures (Scenario 1, see Table 2). According to the HEED, Scenario 1 would save a total of $0.18 \mathrm{MtCO}_{2} \mathrm{e}$ per annum (Table 10). Using AEA (2011) figures, this would reduce Norfolk's 2009 household and overall emissions by $10.9 \%$ and 3.2\% respectively. But as full uptake is unrealistic, Scenario 2 gives an indication, again based on HEED data, of partial uptake across Norfolk which reduces savings by around $0.08 \mathrm{MtCO}_{2} \mathrm{e}$ per annum. The relatively narrow 95\% confidence intervals for an average COA's carbon savings, in both scenarios, suggest a consistency across Norfolk, indicating how the HEED's data resolution could add conviction to policy-making.

In comparison, using EHS data to investigate potential carbon savings produces somewhat different findings, which are in line with the previous discussion of how current insulation levels are represented (Section 4.2). For instance, the EHS shows considerably more savings are achievable through targeting cavity wall insulation than the HEED does, due to the EHS showing more cavities to be unfilled. The HEED and EHS have similar proportions for noncavity walls, which this study targets with external insulation, thus these are not too dissimilar.

COA-level HEED fuel data were used to calculate $\mathrm{CO}_{2} \mathrm{e}$ emissions factors, whereas the EHS had little other option than to adopt the natural gas emissions factor. This is why the HEED indicated higher $\mathrm{CO}_{2} \mathrm{e}$ savings from double glazing provision, despite HEED data being less skewed towards entirely double glazed dwellings (Table 9). COA-weighted fuel cost factors 
similarly implicated the financial investigations because the HEED in general had higher energy costs. 
Table 10 - Carbon saving potential of Norfolk-wide dwelling insulation improvements. Scenarios 1 and 2.

\begin{tabular}{|c|c|c|c|c|c|c|c|c|}
\hline & \multirow{2}{*}{$\begin{array}{c}\text { Insulation } \\
\text { Upgrade }\end{array}$} & \multicolumn{3}{|c|}{ EHS } & \multicolumn{4}{|c|}{ HEED } \\
\hline & & \% of Norfolk's & \multirow{2}{*}{$\begin{array}{l}\text { No. of Norfolk's } \\
\text { dwellings given } \\
\text { retrofit measure }\end{array}$} & \multirow{2}{*}{$\begin{array}{c}\text { Annual } \mathrm{CO}_{2} e \\
\text { Savings }\left(t \mathrm{CO}_{2} e / y r\right)\end{array}$} & \multirow{2}{*}{$\begin{array}{l}\text { \% of Norfolk's } \\
\text { dwellings given } \\
\text { retrofit measure }\end{array}$} & \multirow{2}{*}{$\begin{array}{l}\text { No. of Norfolk's } \\
\text { dwellings given } \\
\text { retrofit measure }\end{array}$} & \multirow{2}{*}{$\begin{array}{c}\text { Annual } \mathrm{CO}_{2} e \\
\text { Savings }\left(t \mathrm{CO}_{2} e / y r\right)\end{array}$} & \multirow{2}{*}{$\begin{array}{c}\mathrm{COA} \text { Mean Annual } \\
\mathrm{CO}_{2} e \text { Savings } \\
\left(t \mathrm{CO}_{2} e / y r\right)[95 \% \text { C.I.] }\end{array}$} \\
\hline & Type & & & & & & & \\
\hline \multirow{8}{*}{ Scenario 1} & Cavity wall & 33.91 & 116,242 & 46,235 & 9.01 & 30,886 & 8,839 & \begin{tabular}{l|l} 
& $3.11[3.01-3.21]$
\end{tabular} \\
\hline & Loft & 69.26 & 237,420 & 24,244 & 66.15 & 226,759 & 34,564 & $\begin{array}{c}12.19[11.92- \\
12.46]\end{array}$ \\
\hline & Glazing & 14.51 & 49,748 & 4,105 & 21.93 & 75,158 & 9,043 & $3.19[3.09-3.28]$ \\
\hline & $\begin{array}{l}\text { Internal solid } \\
\text { wall }\end{array}$ & 13.47 & 46,158 & 84,930 & 13.31 & 45,609 & 63,245 & $\begin{array}{c}21.49[21.28- \\
21.70]\end{array}$ \\
\hline & $\begin{array}{l}\text { External solid } \\
\text { wall }\end{array}$ & 13.47 & 46,158 & 89,575 & 13.31 & 45,609 & 66,705 & \begin{tabular}{c|c}
$22.66[22.45-$ \\
& $22.87]$ \\
\end{tabular} \\
\hline & Total: & - & - & 249,089 & - & - & 182,396 & $62.64[61.75-63.52]$ \\
\hline & Average: & 28.92 & 99,145 & 49,818 & 24.74 & 84,804 & 36,479 & $12.53[12.35-12.70]$ \\
\hline & & & & & & & & \\
\hline \multirow{7}{*}{ Scenario 2} & Cavity wall & 30.52 & 104,618 & 41,612 & 8.11 & 27,797 & 7,955 & $2.80[2.71-2.89]$ \\
\hline & Loft & 62.33 & 213,678 & 21,819 & 59.54 & 204,083 & 31,107 & $\begin{array}{c}10.97[10.73- \\
11.22]\end{array}$ \\
\hline & Glazing & 13.06 & 44,773 & 3,694 & 19.73 & 67,642 & 8,139 & $2.87[2.78-2.95]$ \\
\hline & $\begin{array}{l}\text { Internal solid } \\
\text { wall }\end{array}$ & 3.37 & 11,539 & 21,930 & 3.34 & 11,402 & 15,288 & 5.37 [5.32-5.43] \\
\hline & $\begin{array}{l}\text { External solid } \\
\text { wall }\end{array}$ & 3.37 & 11,539 & 22,394 & 3.34 & 11,402 & 16,124 & $5.67[5.32-5.72]$ \\
\hline & Total: & - & - & 111,449 & - & - & 78,613 & $27.68[26.86-28.21]$ \\
\hline & Average: & 22.53 & 77,229 & 22,290 & 18.81 & 64,465 & 15,723 & $5.54[5.37-5.64]$ \\
\hline
\end{tabular}


The scale of the HEED data facilitates the highlighting of geographic differences, which could potentially provide a rationale for contrasting policy priorities (Table 11). For example, on a LA basis, the Borough Council of King's Lynn and West Norfolk area would yield the greatest savings of the Norfolk LAs largely because it has the largest dwelling stock (23\% higher than the Norfolk LA mean). Broadland District Council area would yield the least savings not because it has the smallest stock ( $2 \%$ less than Norfolk LA average), but because its existing insulation baseline is higher. The EHS' unit of analyses inhibit such insights.

Table 11 - Annual carbon saving potential of Norfolk-wide dwelling insulation improvements $\left.\mathrm{tCO}_{2} \mathrm{e} / \mathrm{yr}\right)$, per local authority, calculated using HEED COA data. Scenario 1.

\begin{tabular}{|l|c|c|c|c|c|c|}
\hline \multicolumn{1}{|c|}{ Local Authority } & $\begin{array}{c}\text { Cavity } \\
\text { wall }\end{array}$ & Loft & Glazing & $\begin{array}{c}\text { Internal } \\
\text { solid wall }\end{array}$ & $\begin{array}{c}\text { External } \\
\text { solid wall }\end{array}$ & Total \\
\hline Breckland & 1,299 & 5,057 & 1,104 & 8,659 & 9,132 & 25,251 \\
\hline Broadland & 1,556 & 4,595 & 796 & 6,965 & 7,346 & 21,258 \\
\hline Great Yarmouth & 837 & 4,845 & 1,144 & 10,023 & 10,571 & 27,420 \\
\hline King's Lynn \& West Norfolk & 1,605 & 5,698 & 1,721 & 9,522 & 10,043 & 28,589 \\
\hline North Norfolk & 1,128 & 4,598 & 1,137 & 7,884 & 8,315 & 23,062 \\
\hline Norwich City & 1,010 & 4,628 & 2,068 & 10,137 & 10,691 & 28,534 \\
\hline South Norfolk & 1,403 & 5,142 & 1,073 & 10,057 & 10,607 & 28,282 \\
\hline \hline Norfolk Mean: & 1,263 & 4,938 & 1,292 & 9,035 & 19,058 & 35,586 \\
\hline \hline Total: & $\mathbf{8 , 8 3 9}$ & $\begin{array}{c}\mathbf{3 4 , 5 6} \\
\mathbf{4}\end{array}$ & $\mathbf{9 , 0 4 3}$ & $\mathbf{6 3 , 2 4 5}$ & $\mathbf{6 6 , 7 0 5}$ & $\begin{array}{c}\mathbf{1 8 2 , 3 9} \\
\mathbf{6}\end{array}$ \\
\hline
\end{tabular}

\subsubsection{Financial implications}

A similar exercise was undertaken to investigate the financial implications of upgrading domestic insulation; investment decisions are particularly pertinent during the economic downturn. Whilst financial implications clearly vary, the HEED and EHS do share broadly similar patterns across the insulation types (Table 12). The differences between the HEED and EHS, as one may expect, manifest themselves in exactly the same manner as the carbon savings assessment. 
Table 12 - Capital costs, annual cost savings and simple payback periods for Norfolk-wide dwelling insulation improvements. Discount factor $=0 \%$.

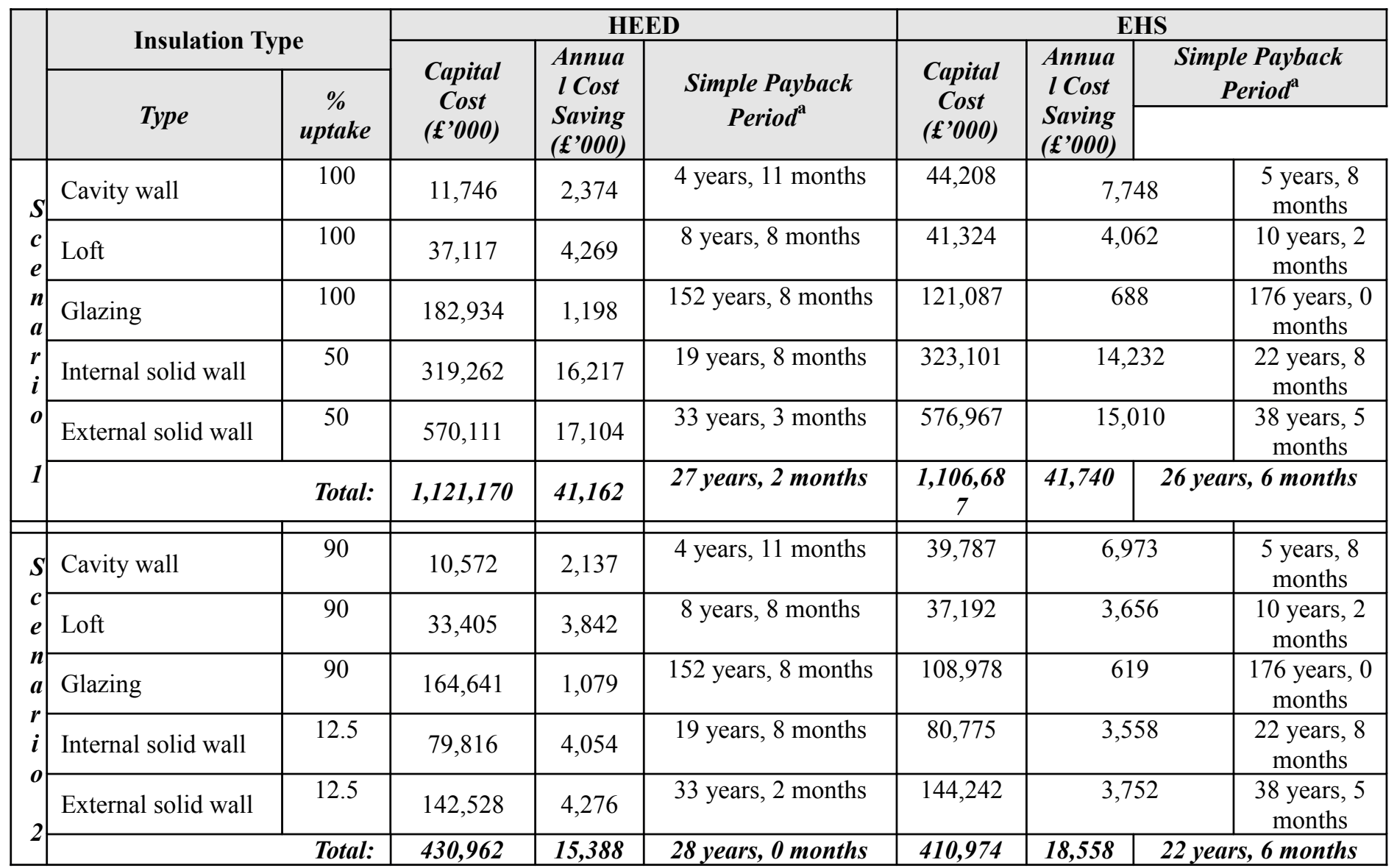

${ }^{\mathrm{a}}$ The simple payback period is a weighted average of total interventions.

The simple payback calculations are in broad agreement. The payback times of internal solid wall insulation, external solid wall insulation and glazing indicate poor cost effectiveness, whichever the data source. In contrast, loft and cavity wall investments are more financially viable, with HEED data providing a more detailed analysis (Table 13).

Table 13 - HEED-derived discounted payback periods for Norfolk-wide loft and cavity wall dwelling insulation improvements. Discount factor $=3.5 \%$. Scenario 1 .

\begin{tabular}{|l|c|c|}
\hline \multicolumn{1}{|c|}{ Local Authority } & Loft Insulation & $\begin{array}{c}\text { Cavity Wall } \\
\text { Insulation }\end{array}$ \\
\hline Breckland & $8 \mathrm{yrs}, 5 \mathrm{mths}$ & $7 \mathrm{yrs}, 1 \mathrm{mths}$ \\
\hline Broadland & $9 \mathrm{yrs}, 4 \mathrm{mths}$ & $7 \mathrm{yrs}, 7 \mathrm{mths}$ \\
\hline Great Yarmouth & $7 \mathrm{yrs}, 2 \mathrm{mths}$ & $7 \mathrm{yrs}, 3 \mathrm{mths}$ \\
\hline King's Lynn \& West Norfolk & $8 \mathrm{yrs}, 1 \mathrm{mths}$ & $7 \mathrm{yrs}, 0 \mathrm{mths}$ \\
\hline North Norfolk & $8 \mathrm{yrs}, 1 \mathrm{mths}$ & $7 \mathrm{yrs}, 1 \mathrm{mths}$ \\
\hline Norwich City & $8 \mathrm{yrs}, 0 \mathrm{mths}$ & $7 \mathrm{yrs}, 11 \mathrm{mths}$ \\
\hline
\end{tabular}




\begin{tabular}{|c|c|c|}
\hline South Norfolk & $8 \mathrm{yrs}, 8 \mathrm{mths}$ & $7 \mathrm{yrs}, 0 \mathrm{mths}$ \\
\hline Total: & $8 \mathrm{yrs}, 3 \mathrm{mths}$ & $7 y r s, 3$ mths \\
\hline
\end{tabular}

The HEED fuel use data can be used as an indicator of resident finances and hence fuel poverty vulnerability. The rural-urban divide dominates this indicator with the urban LA area of Norwich having the cheapest fuel $(3.18 \mathrm{p} / \mathrm{kWh})$, which was considerably lower than the Norfolk County mean of $3.64 \mathrm{p} / \mathrm{kWh}$. The carbon intensity of the heating fuel previously used followed a similar pattern due to the dominance of rural electric heating, which is more carbon intensive than gas central heating largely used in urban areas. For example, the mean $\mathrm{CO}_{2} \mathrm{e}$ emissions factor was $0.214 \mathrm{kgCO}_{2} \mathrm{e} / \mathrm{kWh}$ in Norwich LA of but $0.268 \mathrm{kgCO}_{2} \mathrm{e} / \mathrm{kWh}$ in rural South Norfolk LA.

\subsection{Objective 4 - Examine local socio-demographic and dwelling-specific influences on existing domestic insulation levels}

This paper has so far emphasised that the main advantage of using HEED data over other databases is that it provides insulation, in addition to property-relevant, data at a smaller unit of analysis than its rivals. The benefits of this are now explored further by using COA-level HEED data to tease out local characteristics that shape insulation uptake and to consider them in the context of policy formulation - something that is not possible using other readily available datasets.

All databases have inherent weaknesses and any failings when applying the HEED at this scale should not result in it being discredited. If the HEED is the only database that has this contextual capability then such analyses should be undertaken to diversify our evidence base and help triangulate findings, whilst of course bearing in mind its limitations. Indeed a " $k e y$ 
objective of the NEED data [of which the HEED is a key component] is to enable DECC to build a demand function relating household energy consumption to observable household and dwelling characteristics, with a particular focus on the impact of the adoption of a key set of energy efficiency measures"; hence DECC (2011a: 64) undertook a similar correlation exercise.

\subsection{1 'Hard to Treat' (HTT) dwellings}

HTT dwellings are those that cannot have either gas central heating, cavity wall insulation, or loft insulation. Although no information is available on loft access or existence, the HEED does inform us that $26 \%$ of Norfolk dwellings are off-gas (Appendix 9.1 ) and $27 \%$ are noncavity walled (Table 8). Unfortunately since the HEED does not provide data at dwellinglevel, an absolute number of HTT dwellings cannot be provided. This section nevertheless attempts to investigate the HTT concept using correlation coefficients (Appendix 9.2).

The proportion of flats in a COA positively correlated with dwellings without loft insulation and entirely single glazed, perhaps because most flats have no loft space and replacing highrise windows can be difficult. DECC's (2011a) HEED analysis supports this, showing 7\% of English dwellings received insulation from EEC phase 1 and 2 (2002-2008) compared to 2\% of English flats. There is a slight negative correlation between flats and empty cavities, despite cavity insulation requiring agreement with above/below neighbours, thus could be a result of Government policy or 'chance'.

Property age correlation analyses (Appendix 9.3) showed that prior to 1929 there were considerably less cavity walled dwellings, but following this there was a steady increase. In 
terms of whether these were filled cavities or not, few temporal distinctions were apparent, probably due to past Government-funded cavity insulation diluting any trends. The number of solid and stone walls increased as the proportion of pre-1929 and pre-1900 dwellings increased respectively.

The percentage of pre-1900 dwellings has relatively strong positive correlations with complete single glazing, zero loft insulation, and stone walls which have no cavity to fill. The single glazing trend could be due to building conservation restrictions, loft insulation due to many pre-1900 dwellings having no/limited loft access, and stone wall correlation due to building practices of the time. The highest correlations were associated with pre-1900 dwellings across all insulation types; the implication being that pre-1900 dwellings are more likely to be HTT.

Areas in Norfolk with higher average fuel costs, due to limited access to gas, had very marginally fewer empty cavities (-.050) and more empty lofts (.072). Weak relationships may well be a product of Government efforts to tackle fuel poverty, which electrically heated dwellings are more vulnerable to. Evidence from the HEED thus suggests that targeting electrically heated dwellings may be less of a priority than tackling older properties. Alternatively, it may simply be an artefact of the HEED's non-systematic sampling or demonstrate the relationship's random nature.

\subsubsection{Other notable relationships}

The HEED-Census comparisons for property type and tenure variables showed the Census to consistently have slightly higher correlation coefficients than the HEED. Therefore varying 
Census data has a slightly greater effect in changing insulation level trends, than the equivalent HEED dataset. There is of course no definite way to know which is more or less accurate because we do not fully understand the current situation. But using fairly established generalised conclusions (e.g. social renters and owner occupiers have higher insulation; privately rented and/or flats have lower insulation), it does seem that the 2001 Census is ironically a marginally better predictor of HEED-derived insulation data, than the property type and tenure data from the HEED itself.

Multicollinearity between the predictors was not a problem (mean VIF $=1.15$; no individual VIF >5). Therefore duplication of information (and its associated capability to predict insulation levels) inherent in each predictor was not a problem when applying HEED data (e.g. if using for targeting dwellings).

Using the HEED data, other relationships could be identified between socio-economic or property-related factors and the percentage of dwellings with empty lofts, empty cavities and wholly single glazing (Appendix 9.2 and 9.3):

- Dwellings with condensing boilers are more likely to have loft insulation and filled cavities. This could be an artefact of HEED data being sourced from fuel poverty schemes (e.g. Warm Front) which commonly improve both insulation and heating systems, or a product of simultaneous changes to Building Regulation requirements. Indeed the influence of UK Building Regulations is particularly evident when analysing temporal trends, e.g. areas with high proportions of post-1995 dwellings also have high percentages of dwellings with $\geq 200 \mathrm{~mm}$ loft insulation, filled cavities, and double glazing. 
- Typically the greater the proportion of pre-1929 and post-1950 dwellings, the more single and double glazing respectively. Speculation may lead one to attribute this to: differences in building practices (e.g. construction, property type) over time; Building Regulations improvements; conservation orders restricting window replacement of older windows; and/or the timings of maintenance and replacement cycles.

- Young adults (18-30s) shared a pronounced positive correlation with single glazing (.262), which could be explained by young adults having a positive correlation with flats (.326) and a negative correlation with owner occupied tenure (-.326). However there was no significant or strong correlation between insulation and individuals aged $\geq 65$ years. This is despite fully funded cavity and loft insulation being available through the Warm Front scheme, and DECC (2011a: 17) stating that "approximately half of all households [that have installed a HEED-related energy efficiency measures] have a head of household of 56 or older".

- The higher Benefit Claims per Capita of a COA, the less empty lofts and cavities. DECC (2011a) suggests the root cause of lower income households having a greater uptake of energy efficiency measures is partly due to social support with $18 \%$ socially rented dwellings having received insulation. Therefore these residents do not necessarily have a greater willingness to install such measures, but instead it is merely a consequence of the EEC and CERT schemes prioritising households receiving certain income-related benefits. This, combined with housing associations having a legal duty of care to residents, is the likely rationale behind areas with more social renters being better insulated. It is thus unsurprising that insulation levels were found 
here to be lower in areas with more highly qualified individuals and higher/intermediate managers (excluding glazing). The fact that lowest valued dwellings (band A) positively correlated with lower insulation may simply be a product of structural obstacles (e.g. difficult to insulate flats and solid-walled Victorian terraces).

- The rural/urban variable had no notable relationships with insulation types. Therefore whilst geography was shown to be a primary driver of fuel poverty, as a consequence of rural Norfolk areas being predominantly off gas, rural households were seemingly no more or less likely to have better insulation.

\section{Evaluating the HEED}

This section builds on previous discussion and inferences surrounding what constitutes the HEED and how that can implicate its applications, both in terms of understanding our current dwelling stock and in constructing targeted improvements across certain insulation types and dwelling/household profiles.

\subsection{Data quality and integrity}

Data availability across a range of spatial resolutions (e.g. national, district, COA) enables flexibility in constructing methodologies and can contribute to more statistically significant results. Indeed, over $95 \%$ of findings had $\geq 99.9 \%$ confidence. Although finer sampling can limit geographic biases, aggregated area totals can misrepresent trends. This is historically termed an 'Ecological Fallacy', whereby correlations using area-level totals can contradict 
what is actually happening at the individual household or dwelling level (Robinson, 1950). Therefore, as the database does not drill down to the individual level, no direct causal links can be stated as a result of HEED analysis alone. This said, the use of individual dwelling data are not without its own problems: for example, DECC (2011a) excluded flats, which are often HTT, from its analysis because the dwelling-level data did not adequately match address reference numbers.

Since $55 \%$ and $72 \%$ of HEED-Norfolk's individual data items and dwelling coverage respectively were collected through opportunistic sources when energy saving improvements were installed, more dwellings are likely to be shown as needing no improvement than there are in reality. Thus carbon and cost estimates drawn from it are likely to be conservative. Nevertheless, upon installation other information is typically recorded (e.g. property age/type recorded when installing loft insulation), and the $17 \%$ difference between data item and dwelling coverage indicates that the non-opportunistic data sources (e.g. EST's HEC) contribute more data per data collection exercise (e.g. survey). A high reliance on data collected during installation means that a significant number of privately installed insulation projects are likely to be missed. The dominance of Government funding in the past for cavity and loft insulation is likely to be the reason behind glazing (no funding available) trends being radically different.

On average the HEC makes up $66 \%$ of insulation data (11\% of Norfolk dwellings). Despite being one of the few sources that pro-actively collect data, it lacks reliability since it is reliant on householder, not expert, judgement. Self-selection bias is another key limitation as certain (e.g. interested) individuals are more likely to participate. Nevertheless online surveying such as the HEC does enable an efficient means to access wider parts of society. One could 
speculate that HEC coverage could act as a proxy for a LA's householder interest in energy efficiency issues, as a HEC's completion is largely resident-motivated.

The EST state that the HEED contains information on $51 \%$ of UK dwellings, but it is important to emphasise that "information" may only include a lone variable input. If just insulation data were taken into consideration the mean sample size was $16.85 \%(64,624$ Norfolk dwellings). On average the non-insulation HEED variables covered $1.47 \%$ more of Norfolk's dwellings $(5,638)$ than insulation-specific variables. However the main fuel heating type had the largest sample of $23.65 \%(90,703)$, thereby increasing the representativeness of each COA's fuel cost and carbon emission factors produced using the HEED.

The date ranges of some key contributing datasets were unknown (Table 1). Transparency and accountability is essential for the HEED as the collection and installation dates of the source data are interchangeably used across certain data sources. Moreover, greater clarity is needed to enable users to take full advantage of the HEEDonline's filtering function which allows data from only specified date ranges to be downloaded.

HEED data have been unsystematically collected across a number of years, which has led to the assumption that a 'fact' remains true until more up-to-date data are collected on that same dwelling (overwriting it with a new 'fact'). For example, householders may have filled their cavity wall without grant assistance since HEED data were collected 3 years earlier, thus suggesting that initial indications of conservative projections may be unfounded. This is a reason for storing data on a dwelling basis (without personal details) as it allows for more recent data to overwrite older data equivalents, as well as avoiding double counting. Whilst data source rankings are applied to allow highly reliable data (e.g. Fuel Poverty Scheme: 
survey undertaken by qualified surveyors) to replace the less reliable data (e.g. HEC: based on householder judgements), an increased reliability does not resolve the fact that it is a hybrid of newer and older data, the ratio of which is unknown. Since the scale and coverage of the HEED makes it difficult to incorporate systematic data collections with clear data collection timescales, the EST should continue to progress towards more frequent data collection (to facilitate more 'overwriting') and greater transparency of when these collections took place.

The rationale behind the boundaries categorising the variables is at times ambiguous, or at the very least represents an obstacle to analysis. For example, the application of a Standard Assessment Procedure like survey for data collection means that 'year of construction' bands vary in duration from 5 to 30 years. It is likely that much of the seemingly ambiguous nature of the variables' boundaries can be attributed to artefacts of data collection, rather than a systematic drawing of boundaries for analytical purposes. It is clear that decisions surrounding band allocation could shape the potential effectiveness of the HEED. This is illustrated by the general 'double glazing' category being the most efficient glazing band with an average $66 \%$ of dwellings falling into it. Recording other information (e.g. low emissivity coatings, argon fills, cavity thickness) or even triple glazing could provide scope for more detailed analysis particularly in the future. Although real-world circumstances can never truly be represented by rigid categories, additional sub-categorisation may go some way to improving the representation of reality. For example, the inclusion of a 'Partial Fill' category (e.g. mainly solid walled dwellings with cavity-walled extensions) applies to $19.4 \%$ of dwellings without cavity wall insulation, based on past Northern Ireland trends (Pett, 2004). 
For the HEED's Government-set objectives to be achieved, improvements are needed. For instance, increasing HEC participant numbers via promotion and improving data filtering capabilities so that specific datasets can be utilised alone. Representativeness could also be improved by incorporating systematic sampling (e.g. EHS dwelling data which is already available but only labelled by region) or focusing on socio-demographics that are lacking in the database. However the HEED's opportunistic nature, whilst facilitating low operational costs, makes immediate improvements unlikely with budget cuts pending. Nevertheless, the recent upgrade will have increased sample size (e.g. CERT years 1 and 2: 19.1 million additional data items) and dramatically reduced data extraction times which limited the scope of this study ${ }^{\mathrm{ii}}$.

The HEED should be adapted if it is to provide evidence for carbon reduction policy and research, such as the long-term challenge of climate change mitigation. For example, as the thermal efficiency of dwellings improves, the HEED could facilitate long-term planning through collecting data on electrical appliances, a concern which DEFRA (2008) highlights in the context of developing HEC surveys. If the HEC data are to be utilised effectively, the data storage and analytical boundaries of the HEED will also need to evolve.

\subsection{Potential applications}

Since significant progress has already been made to improve the insulation of 'Easy to Treat' dwellings (e.g. only $12 \%$ of cavity walls are empty), the longer term priority to reducing carbon emissions is to tackle HTT dwellings, which account for $43 \%$ of England's stock (Beaumont, 2007). This Norfolk case study showed fuel use (i.e. off the gas network) to be the dominant trigger of HTT status unlike the national trend of solid walls. HEED's data 
resolution thus allows local contexts across varying scales to be highlighted. For example, Norwich had higher proportions of flats, terraces, gas heating, and privately rented tenures than much of its surrounding rural areas. Such information could be of great use when developing local residential sustainability strategies.

An appreciation of local context through data reviews and correlation exercises can also assist with the identification of key geographic areas with lower insulation levels (e.g. areas dominated by privately rented tenure, flats) and HTT dwellings. The carbon saving potentials of individual COAs could be used for prioritisation. With this potential in mind, it is unsurprising that the EST restrict HEED access to different organisations (e.g. insulation door-to-door sales companies).

Significant opportunities also exist in utilising the HEED data as part of larger scale assessments (i.e. regional, national); for instance, in facilitating the Green Deal and targeting the fuel poor. Evidence from the HEED, in conjunction with the EHS, Census and other databases, could thus be invaluable in decision-making, particularly if key sampling concerns are addressed in the long-term. Meanwhile, should organisations use HEED data to appraise policy decisions (e.g. identifying cheaper 'quick win' options), sampling biases must be considered as the HEED can indicate dwelling insulation levels to be higher than in actuality.

Inevitably the potential applicability of the HEED is dependent on access, which the EST assesses and awards on a case-by-case basis. When initiating this study, access was granted on a COA basis which was the lowest unit of analysis available. Since this time, as the NEED framework has come to the fore, it would seem that UK Government-associated analysis are able to utilise dwelling level data (e.g. DECC, 2011a). However, although flexible to a certain 
extent depending on each project's scope and purpose, the default data availability (for nonGovernmental analysis) was increased in February 2011 to the LA level. The size of the dataset and its resolution are its core strengths and what makes it potentially useful in directing policy. It helps provide a well-rounded view of local context which other databases do not facilitate - hence we recommend making as much high resolution HEED data available as possible, providing Data Privacy agreements are not compromised.

\subsection{Policy implications of the HEED}

The need for evidence-based policy-making can be, in part, addressed by using the HEED. Whilst there are biases associated with HEED's data collection, we agree with Wyatt's (2013: 540) assertion that using existing data (as the HEED does) is "a practical alternative" to the traditionally used and more resource intensive on-the-ground surveys. However, in addition to the HEED being a convenient and cost effective means of collating data, Section 4 in particular emphasised how that data can enable local and contextual insight.

It is this enhanced understanding of local context that makes the HEED especially useful in identifying geographic areas that are in most need of retrofitting measures. Through understanding how policies could practically and most efficiently be acted upon at the ground-level, funding prioritisation should also be enabled. For example, the HEED could help identify Hard to Treat dwellings (as discussed in Subsection 4.4.1), which are explicitly being targeted in the UK as part of the Energy Companies Obligation. As such, energy supply companies could use the HEED to select which geographic area(s) to prioritise. The underlying assumptions (e.g. baseline insulation levels) of policies could also be critiqued through applying HEED data, which would strengthen the evidence base of (and potential 
allow for a re-steering of) relevant central and local government policies. For instance, a more detailed understanding of insulation levels would make it easier for governments to estimate the effect of policies on future energy demand and prices.

It is the appreciation of local context that the HEED data facilitates, which leads this paper to agree with Hamilton et al. (2013: 464) who believe that the HEED "presents an opportunity from which to develop an energy efficiency evidence base for policy development and evaluation". Indeed the benefits of data frameworks, such as the HEED, are not merely UKspecific. There is a case for HEED-like databases in other countries; for those countries will inevitably have their own contextual circumstances that will need to be understood if effective retrofitting policies are to be produced and then delivered.

Nevertheless, whilst a rich resource with much to offer, we suggest that HEED users and policy-makers remain wary of the biases inherent to the HEED. For instance, as Section 4 illustrated, much of the HEED is made up of dwellings that have had retrofit measures delivered. This thereby reiterates the somewhat ironic point that, unless significant efforts are made to systematically collect data on dwellings that have not be retrofitted to some degree, "those dwellings not in the HEED must be the targets" (Hamilton et al., 2013: 475) of domestic energy efficiency policies.

\subsection{Study limitations}

This study has focused on insulation with the rationale that a 'fabric first' ethos is best practice. Therefore the HEED's microrenewables installation data, which at the time of data collection were primarily sourced from the Low Carbon Buildings Programme and Clear 
Skies funding initiatives (Table 1), were excluded. The need to prioritise also led to the exclusion of data such as heating controls, hot water tank type/insulation, and other installation information. Therefore, despite the usefulness of some of the data being limited (e.g. lower sampling coverage, inability to provide accurate installation rates (e.g. low energy lamps)), the full potential of the HEED has not been wholly conveyed by this study.

Although Norfolk averages were included for comparative purposes, national or regional averages from the HEED would have provided more suitable comparisons against Census and EHS values. This study's findings are inherently context specific; hence similar work in other UK locations could prove useful. A deviant sampling approach could help examine a contrasting (e.g. predominantly urban) region.

The nature of using a database that has seldom been used in the public domain meant that current awareness, perceptions and uses of the HEED were unknown. Interviews delving into such issues with, for example, LAs or research bodies could indicate feasible and effective directions for the HEED or other future databases aiming to enable a low carbon transition.

\section{Conclusions}

This paper uses Norfolk (UK) as a case study to inspect the Homes Energy Efficiency Database (HEED) as a research resource in terms of its integrity, reliability, and usefulness as a data source. The average coverage of dwellings across the HEED variables was $17.77 \%$, with clear geographic and variable type variations evident (range: 7.30-28.42\%). Closer investigation of the variables showed that the HEED's reactive data collection contributed to contrasting representations relative to DCLG (2011), Census, and English Housing Survey 
(EHS) data (e.g. HEED's underrepresentation of social renters). These underlying biases led to certain domestic insulation levels being shown, as the HEED-EHS comparisons demonstrated, which then manifested themselves in the indicative carbon and cost assessments of insulation improvements (e.g. HEED's overrepresentation of 'filled' cavity walls indicating cavity insulation policies to be a cheaper with less emissions savings likely). These analyses repeatedly emphasised the appreciation of local context that the HEED enabled, the fringes of which were further explored by correlation exercises. For instance, analysis demonstrated that the dominant factor in classifying Norfolk dwellings as 'Hard to Treat' is being off the gas network, instead of being a solid wall construction as is the dominant factor nationally. This is an advert for localism and a warning to those basing research and policy decisions on national or regional generalised assumptions: local context needs greater appreciation.

It is extremely difficult to construct a database, without weaknesses, that details the condition of a nation's existing dwelling stock. Weaknesses need to be transparently presented so that the limitations associated with its applications are visible and acknowledged. In the case of the HEED, its strengths (e.g. high resolution, national coverage) do not automatically ensure a true reflection of reality (e.g. as a consequence of the data's reactive, longitudinal and aggregated nature). Considering the HEED is yet to be widely tested, the provision of such information is a key output of this paper.

The HEED has the potential to make a significant contribution to aiding research and policymaking surrounding UK dwelling retrofits. In spite of sampling-related issues it could be used as a vehicle for change, helping to debate potential policy routes (e.g. community targeting strategies). Indeed all data sources have a role to play in challenging current 
thinking, particularly in light of the very challenging UK Government domestic insulation targets. It is essential that the evidence base is diverse because inevitably each database will have its own unique strengths and limitations, thereby representing different visions of reality, as the HEED-EHS comparisons demonstrate. These relative representations need to be contrasted to suitably understand relevant policy commitments. As society starts to tackle climate change in earnest, more evidence will be sought particularly to establish the current baseline situation so as to enable the focusing of limited resources. This paper thus endorses the 'opening up' of the HEED - in addition to other NEED and energy supplier meter data to the research community in terms of access, as far as data protection and privacy legalities allow.

\section{Acknowledgements}

Thanks must be given to the Energy Saving Trust for allowing access to the HEED; in particular, Simon Elam, Patrick Dwyer and David Davies for clarifying HEED-related queries necessary for this study. Many thanks also to both anonymous reviewers for their insightful comments. The primary researcher of this study was funded by the UK Economic and Social Research Council (Grant number: ES/H011129/1). 


\section{References}

ACE [UK Association for the Conservation of Energy] (2011) Scaling the solid wall: Final report for Consumer Focus, London: Association for the Conservation of Energy.

AEA (2011) Local and Regional CO2 Emissions Estimates for 2005-2009, London: DECC.

Beaumount, A. (2007) Hard to Treat Homes in England, Buildings Research Establishment, Presented at the Sustainable Urban Areas Conference, Rotterdam [online], Available: http://www.enhr2007rotterdam.nl/documents/W07_paper_Beaumont.pdf (25-28 June 2007).

BRE [Buildings Research Establishment] (2003) Standards of Performance 2: Findings from Monitoring, BRE Client Report 16099, Watford: Buildings Research Establishment.

BRE [Buildings Research Establishment] (2010) SAP 2009: The Government's Standard Assessment Procedure for Energy Rating of Dwellings, Watford: BRE.

CCC [Committee on Climate Change] (2008) Building a low-carbon economy - the UK's contribution to tackling climate change, The First Report of the Committee on Climate Change, London: The Stationery Office.

CCC [Committee on Climate Change] (2010) The Fourth Carbon Budget: Reducing emissions through the 2020s, London: CCC.

DCLG [UK Department for Communities \& Local Government] (2010a) English Housing Survey: Headline Report 2008-09, London: DCLG.

DCLG [UK Department for Communities \& Local Government] (2010b) English Housing Survey: Housing Stock Report 2008, London: DCLG.

DCLG [UK Department for Communities \& Local Government] (2011) Table 100: Number of dwellings by tenure and district, England: 2009, 2010 and 2011, Live tables on dwelling stock (including vacants), [online], Available: http://www.communities.gov.uk/housing/housingresearch/housingstatistics/housingstatisticsby/stockinc ludingvacants/livetables/ (Updated 11 November 2011).

DCLG [UK Department for Communities \& Local Government] (2013) English Housing Survey Technical Advice Note - Sampling and weighting: 2011-12 Update, London: DCLG.

DECC [UK Department of Energy and Climate Change] (2010) Retail prices index: fuel components, [online], Available: http://www.decc.gov.uk/assets/decc/statistics/source/ prices/qep211.xls (24 June 2010).

DECC [UK Department of Energy and Climate Change] (2011a) National Energy Efficiency Data-Framework: Report on the development of the data-framework and initial analysis, London: DECC.

DECC [UK Department of Energy and Climate Change] (2011b) The Carbon Plan: Delivering our low carbon future, London: DECC.

DECC [UK Department of Energy and Climate Change] (2012) Emissions from Heat: Statistical Summary, London: DECC.

DEFRA [UK Department for Environment, Food and Rural Affairs] (2008) Promotion of Energy End-use Efficiency and Energy Services: Implementing Directive 2006/32/EC in the UK, Energy Services Directive - Data Requirements Report, London: DEFRA.

Dresner, S. \& Ekins, P. (2004) Economic Instruments for a Socially Neutral National Home Energy Efficiency Programme, London: Policy Studies Institute.

Element Energy (2008) The growth potential for Microgeneration in England, Wales and Scotland, Element Energy: Cambridge.

ESDS [Economic and Social Data Service] (2011) Core data in use, [online], Available: http://www.esds.ac.uk/resources/datainuse/coreinuse.asp (Updated 28 July 2011).

EST [Energy Saving Trust] (2006) 'Appendix C: A Paper by the Energy Savings Trust on the Advantages of Using the HEED Database', In: Annex A - A Consultation by the Scottish Building Standards Agency on Implementation of Articles 7,8 and (of the EU Directive on the Energy Performance of Buildings, $\mathrm{p}$. 44, Edinburgh: Scottish Government.

EST [Energy Saving Trust] (2010) Energy Saving Assumptions, [online], Available: http://www.energysavingtrust.org.uk/Energy-saving-assumptions (Accessed 1 December 2010).

EST [Energy Saving Trust] (2012) Guidance notes on CERT reports from HEED, London: Energy Saving Trust.

Friends of the Earth (2009) Get serious about $\mathrm{CO}_{2}$ media briefing, Carbon descent: delivering a sustainable future, [online], Available: http://www.foe.co.uk/resource/media_briefing/carbon_descent_jobs_research.pdf (25 June 2009).

Hamilton, I.G., Steadman, P.J., Bruhns, H., Summerfield, A.J. \& Lowe. R. (2013) 'Energy efficiency in the British housing stock: Energy demand and the Homes Energy Efficiency Database', Energy Policy, 60, pp. $462-480$.

Henderson, G. (2004) Monitoring Energy Savings achieved from Insulation Measures installed in Gas Heated 
Homes in SoP3 and EEC Schemes, Energy Saving Trust, [online], Available: http://www.decc.gov.uk/en/content/cms/what_we_do/consumers/saving_energy/analysis/analysis.aspx (31 September 2004).

Hill, N., Walker, H., Beevor, J. \& James, K. (2011) 2011 Guidelines to DEFRA / DECC's GHG Conversion Factors for Company Reporting: Methodology Paper for Emission Factors, London: DEFRA.

HM Treasury (2003) The Green Book: Appraisal and Evaluation in Central Government, Treasury Guidance, London: The Stationery Office.

HM Government (2009) The UK Low Carbon Transition Plan: National strategy for climate and energy, London: The Stationery Office

Hong, S.H., Oreszcyn, T., Ridley, I. \& the Warm Front Study Group (2006) 'The impact of energy efficient refurbishment on the space heating fuel consumption in English dwellings', Energy \& Buildings, 38 (10), pp. 1171-1181.

House of Commons Energy and Climate Change Committee (2010) Fuel Poverty: fifth report of session 200910, Vol. 1: Report, together with formal minutes, London: The Stationery Office.

House of Commons Environment, Food and Rural Affairs Committee (2008) Energy Efficiency and Fuel Poverty, Fifth Special Report of Session 2007-08, London: The Stationery Office.

Iwaszkiewicz, C., Christofides, J., Wright, W., Thompson, R., Connaughton, J., Hayes-Lewin, B. \& Newey, R. (2010) Study on hard to fill cavity walls in domestic dwellings in Great Britain, Inbuilt Ltd \& David Langdon, [online], Available: http:/www.decc.gov.uk/assets/decc/what\%20we\%20do/supporting $\% 20$ consumers/saving_energy/analysis/788-hard-to-fill-cavity-walls-domestic.pdf (28 October 2010).

London Borough of Lewisham (2010) Local warming: increasing home insulation in Lewisham, A review by the Sustainable Development Select Committee, [online], Available: http://www.lewisham.gov.uk/NR/rdonlyres/57068080-047F-4F6B-8C6107D747A96AF0/0/LocalWarmingHomeInsulationReview.pdf (Accessed 30 October 2010).

Martin, C. \& Watson, M. (2006) Measurement of energy savings and comfort levels in houses receiving insulation upgrades, Energy Monitoring Company, Prepared for Energy Saving Trust, [online], Available: http://www.decc.gov.uk/en/content/cms/what_we do/consumers/saving_energy/analysis/analysis.aspx (31 June-2006).

ONS [UK Office of National Statistics] (2012) Statistical Bulletin: Consumer Price Indices December2011, London: ONS.

OPSI [UK Office of Public Sector Information] (2008) Climate Change Act 2008 - 2008 Chapter 27, London: The Stationery Office.

Pett, J. (2004) Affordable warmth in hard to heat homes: progress report, London: Association for the Conservation of Energy.

Porritt, S., Shao, L., Cropper, P. \& Goodier, C. (2011) 'Adapting dwellings for heat waves', Sustainable Cities and Society, 1 (2011), pp. 81-90.

Ravetz, J. (2008) 'State of shock - What do we know about existing buildings and their future prospects?', Energy Policy, 36 (12), pp. 4462-4470.

Roberts, S., White, V., Preston, I. \& Thumin, J. (2007) Assessing the Social Impacts of a Supplier Obligation: A study for Defra, Bristol: Centre for Sustainable Energy.

Robinson, W.S. (1950) 'Ecological Correlations and the Behavior of Individuals', American Sociological Review, 15 (3), pp. 351-357.

Shorrock, L.D., Henderson, J. \& Utley, J.I. (2005) Reducing carbon emissions from the UK housing stock, Watford: Buildings Research Establishment.

Skea, J. (2012) 'Research and evidence needs for decarbonisation in the built environment: a UK case study', Building Research \& Information, 40 (4), pp. 432-45.

Utley, J.I. \& Shorrock, L.D. (2008) Domestic Energy Fact File 2008, Watford: Buildings Research Establishment.

Wyatt, P. (2013) 'A dwelling-level investigation into the physical and socio-economic drivers of domestic energy consumption in England', Energy Policy, 60, pp. 540-549. 


\section{Appendix}

Appendix 9.1 - Comparing Norfolk averages taken from the Homes Energy Efficiency Database (HEED) against the regional equivalent variables from the Dwelling Survey sample of the English Housing Survey (EHS)

\begin{tabular}{|c|c|c|c|}
\hline \multicolumn{2}{|c|}{ HEED (Norfolk) } & \multicolumn{2}{|c|}{ EHS (East of England) } \\
\hline Variable & $\begin{array}{l}\text { Proportion of } \\
\text { Dwellings (\%) }\end{array}$ & Variable & $\begin{array}{l}\text { Proportion of } \\
\text { Dwellings (\%) }\end{array}$ \\
\hline \multicolumn{4}{|l|}{ Year of Construction: } \\
\hline Pre-1900 & 15.95 & Pre-1850 & 4.33 \\
\hline $1900-1929$ & 7.30 & $1850-1899$ & 7.25 \\
\hline 1930-1949 & 11.85 & 1900-1918 & 5.03 \\
\hline $1950-1965$ & 19.63 & 1919-1944 & 10.82 \\
\hline $1966-1976$ & 18.56 & $1945-1964$ & 23.63 \\
\hline $1977-1981$ & 8.59 & $1965-1974$ & 15.74 \\
\hline $1982-1990$ & 8.31 & $1975-1980$ & 9.14 \\
\hline $1991-1995$ & 4.37 & $1981-1990$ & 8.98 \\
\hline Post-1995 & 5.44 & Post-1990 & 15.09 \\
\hline \multicolumn{4}{|l|}{ Main Heating Fuel: } \\
\hline Gas & 73.88 & $\mathrm{Gas}^{\mathrm{a}}$ & 76.26 \\
\hline Electric & 7.45 & Electric $^{\mathrm{b}}$ & 11.68 \\
\hline Oil & 14.17 & Oil & 8.49 \\
\hline Solid Fuel & 2.35 & Solid Fuel $^{\mathrm{c}}$ & 1.19 \\
\hline LPG & 2.15 & $\mathrm{LPG}^{\mathrm{d}}$ & 0.59 \\
\hline Paraffin & 0.00 & $\begin{array}{l}\text { Community Heating from } \\
\text { CHP/Waste Heat }\end{array}$ & 1.78 \\
\hline \multicolumn{4}{|l|}{ Tenure: } \\
\hline Owner Occupied & 82.33 & Owner Occupied & 55.76 \\
\hline Privately Rented & 13.08 & Privately Rented & 16.50 \\
\hline LA Rented & 1.96 & LA Rented & 10.92 \\
\hline HA Rented & 1.59 & Registered Social Landlord $^{\mathrm{e}}$ & 16.82 \\
\hline Other & 0.62 & & \\
\hline \multicolumn{4}{|l|}{ Property Type: } \\
\hline Detached $^{\mathrm{f}}$ & 43.45 & Detached & 35.43 \\
\hline Semi-Detached $^{\mathrm{e}}$ & 31.12 & Semi-Detached & 23.38 \\
\hline Terrace & 17.17 & Terrace & 26.10 \\
\hline Flats & 7.80 & Flats $^{\mathrm{f}}$ & 14.81 \\
\hline Other & 0.47 & Non-Residential & 0.28 \\
\hline \multicolumn{4}{|l|}{ Main Heating System: } \\
\hline $\begin{array}{l}\text { Condensing Boiler with } \\
\text { Radiators }\end{array}$ & 34.88 & $\begin{array}{l}\text { Boiler System with } \\
\text { Radiators }\end{array}$ & 84.69 \\
\hline Boiler with Radiators & 39.91 & Electric Storage Heaters & 9.68 \\
\hline $\begin{array}{l}\text { Combi Boiler with } \\
\text { Radiators }\end{array}$ & 8.19 & Warm Air Systems & 1.24 \\
\hline $\begin{array}{l}\text { Back boiler with } \\
\text { Radiators }\end{array}$ & 3.67 & Room Heaters & 2.54 \\
\hline Electric Storage Heaters & 7.37 & Other Systems & 0.05 \\
\hline Warm Air & 1.33 & Communal & 1.78 \\
\hline Room Heaters & 4.01 & & \\
\hline Open/Flame Effect Fires & 0.64 & & \\
\hline
\end{tabular}

a The EHS disaggregates 'Gas' into 'Mains', 'Bottled Gas - Propane', and 'Bulk/LPG'. The latter has been separated out in this table to allow further comparison with the HEED categorisations.

b The EHS disaggregates 'Electric' into 'Standard Tariff', '7hr On Peak', '7hr Off Peak', '10hr Off Peak', and

'24hr Heating Tariff'.

' The EHS disaggregates 'Solid Fuel' into 'Coal', 'Smokeless Fuel', 'Anthracite Nuts', and 'Wood'. 
d 'Registered Social Landlords' mainly include Housing Associations, but also other dwellings available through trusts and co-operatives. It is therefore roughly equivalent to the HEED's 'HA Rented' and 'Other' tenures combined.

${ }^{\mathrm{e}}$ HEED actually totals both Detached and Semi-Detached Bungalows and Houses separately.

f The EHS disaggregates 'Flats' into 'Purpose-Built Block' and 'Converted House/Some Other Kind of Building'.

\subsection{Correlation matrix: Correlation coefficients $(R)$ between the percentage of} dwellings requiring complete insulation upgrades and key influences

\begin{tabular}{|c|c|c|c|c|}
\hline Variable & Source & $\begin{array}{l}\text { Empty Lofts } \\
(\%)(\mathrm{N}=\mathbf{2 , 8 3 3 )}\end{array}$ & $\begin{array}{l}\text { Empty Cavities } \\
(\%)(\mathrm{N}=2,841)\end{array}$ & $\begin{array}{c}\text { Wholly Single } \\
\text { Glazed }(\%) \\
(\mathbf{N}=\mathbf{2 , 8 3 7 )}\end{array}$ \\
\hline Built pre-1900 (\%) & HEED & $.103^{* *}$ & $-.131^{* *}$ & $.412^{* *}$ \\
\hline Average fuel cost $(\mathrm{p} / \mathrm{kWh})$ & HEED & $.072^{* *}$ & $-.050^{* *}$ & .027 \\
\hline $\begin{array}{l}\text { Condensing boiler with radiators as } \\
\text { main heating system }(\%)\end{array}$ & HEED & $-.094^{* *}$ & $-.062^{* *}$ & $.083^{* *}$ \\
\hline Flats $(\%)$ & HEED & $.214^{* *}$ & $-.038^{*}$ & $.318^{* *}$ \\
\hline Owner occupied tenure $(\%)$ & HEED & $-.070^{* *}$ & $.193^{* *}$ & $-.327^{* *}$ \\
\hline Flats $(\%)$ & Census & $.217^{* *}$ & $-.050^{* *}$ & $.348^{* *}$ \\
\hline Owner occupied tenure $(\%)$ & Census & $-.114^{* *}$ & $.200^{* *}$ & $-.420^{* *}$ \\
\hline Council tax band 'A' dwellings (\%) & Census & $.068^{* *}$ & $-.187^{* *}$ & $.330^{* *}$ \\
\hline Aged $18-30(\%)$ & Census & $.066^{* *}$ & $-.055^{* *}$ & $.262^{* *}$ \\
\hline Higher \& intermediate managers $(\%)$ & Census & $.079^{* *}$ & $.239^{* *}$ & $-.059^{* *}$ \\
\hline Two highest qualification levels (\%) & Census & $.117^{* *}$ & $.155^{* *}$ & $.194^{* *}$ \\
\hline Economically active $(\%)$ & Census & .013 & $.109^{* *}$ & -.016 \\
\hline Benefit claims per capita & Census & $.075^{* *}$ & $-.191^{* *}$ & $.263^{* *}$ \\
\hline Urban/rural (dummy variable) & Census & $.042^{*}$ & -.007 & .008 \\
\hline
\end{tabular}

${ }^{*} p<.05 ;{ }^{* *} p<.01$

\subsection{Correlation matrix: Assessing the strength of relationship between property age and} insulation

\begin{tabular}{|c|c|c|c|c|c|c|c|c|c|}
\hline Variable & $\begin{array}{l}\text { Pre- } \\
1990 \\
\end{array}$ & $\begin{array}{c}1990- \\
29 \\
\end{array}$ & $\begin{array}{c}1930- \\
49 \\
\end{array}$ & $\begin{array}{c}1950- \\
65 \\
\end{array}$ & $\begin{array}{c}1966- \\
76 \\
\end{array}$ & $\begin{array}{c}1977- \\
81 \\
\end{array}$ & $\begin{array}{c}1982- \\
90\end{array}$ & $\begin{array}{c}1991- \\
95 \\
\end{array}$ & $\begin{array}{l}\text { Post- } \\
1995 \\
\end{array}$ \\
\hline \multicolumn{10}{|c|}{ External Wall Type $(N=2,841):$} \\
\hline Solid & $.574^{* *}$ & $.515^{* *}$ & -.044 & $-.265^{* *}$ & $-.300^{* *}$ & $-.207^{* *}$ & $-.140^{* *}$ & $-.067^{* *}$ & $-.085^{* *}$ \\
\hline Stone & $.333^{* *}$ & .036 & $-.063^{* *}$ & $-.086^{* *}$ & $-.093^{* *}$ & $-.080^{* *}$ & $-.051^{* *}$ & $-.053^{* *}$ & $-.038^{*}$ \\
\hline $\begin{array}{l}\text { Timber } \\
\text { framed }\end{array}$ & $.083^{* *}$ & $-.058^{* *}$ & $-.077^{* *}$ & $-.073^{* *}$ & -.002 & .016 & .035 & .005 & $.079^{* *}$ \\
\hline Empty cavity & $-.131^{* *}$ & $-.071^{* *}$ & $-.060^{* *}$ & $-.077^{* *}$ & $.054^{* *}$ & $.069^{* *}$ & $.170^{* *}$ & $.121^{* *}$ & .028 \\
\hline Filled cavity & $-.599^{* *}$ & $-.409^{* *}$ & $.107^{* *}$ & $.315^{* *}$ & $.272^{* *}$ & $.177^{* *}$ & $.065^{* *}$ & .035 & $.050^{* * *}$ \\
\hline Cavity walled & $-.664^{* *}$ & $-.448^{* *}$ & $.090^{* *}$ & $.299^{* *}$ & $.300^{* *}$ & $.207^{* *}$ & $.126^{* *}$ & $.078^{* *}$ & $.061^{* *}$ \\
\hline Other & $.243^{* *}$ & -.027 & $-.080^{* *}$ & $-.106^{* *}$ & $-.044^{*}$ & -.036 & .006 & -.031 & .021 \\
\hline \multicolumn{10}{|c|}{ Loft Insulation Thickness $(\mathrm{mm})(\mathrm{N}=2,833)$ : } \\
\hline 0 & $.168^{* *}$ & $.99^{* *}$ & -.028 & -.032 & -.020 & -.036 & $-.076^{* *}$ & $-.062^{* *}$ & $-.075^{* *}$ \\
\hline$<25$ & .002 & -.012 & $-.037^{*}$ & -.004 & .009 & .022 & .001 & .015 & .012 \\
\hline $25-29$ & -.012 & .006 & .001 & .012 & -.004 & $.073^{* *}$ & -.004 & -.031 & $-.038^{*}$ \\
\hline $50-74$ & .028 & -.034 & $-.047^{*}$ & .000 & .023 & $.083^{* *}$ & .026 & -.010 & $-.088^{* *}$ \\
\hline $75-99$ & -.009 & .008 & .028 & $.038^{*}$ & -.018 & .012 & -.022 & .013 & $-.062^{* *}$ \\
\hline $100-149$ & -.030 & $-.055^{* *}$ & -.036 & -.017 & -.006 & -.032 & $.072^{* *}$ & $.106^{* *}$ & .035 \\
\hline $150-199$ & $-.040^{*}$ & $-.080^{* *}$ & -.005 & $-.048^{*}$ & -.010 & -.031 & -.005 & $.084^{* *}$ & $.201^{* * *}$ \\
\hline $200-249$ & -.024 & -.033 & .018 & -.001 & -.013 & $-.052^{* *}$ & -.012 & .016 & $.119^{* *}$ \\
\hline $250-299$ & $-.048^{*}$ & $.082^{* *}$ & $.067^{* *}$ & $.050^{* *}$ & .023 & .012 & -.009 & $-.114^{* *}$ & $-.097^{* *}$ \\
\hline \multicolumn{10}{|c|}{ Glazing $(N=2,837):$} \\
\hline Single & $.302^{* *}$ & $.216^{* *}$ & $.085^{* *}$ & $-.146^{* *}$ & $-.176^{* *}$ & $-.045^{*}$ & $-.051^{* *}$ & $-.093^{* *}$ & $-.129^{* *}$ \\
\hline $\begin{array}{l}1-50 \% \\
\text { Double }\end{array}$ & $.301^{* *}$ & $.182^{* *}$ & .032 & $-.118^{* *}$ & $-.109^{* *}$ & $-.073^{* *}$ & $-.073^{* *}$ & $-.102^{* *}$ & $-.110^{* *}$ \\
\hline
\end{tabular}




\begin{tabular}{|l|c|c|c|c|c|c|c|c|c|}
\hline $\begin{array}{l}51-99 \% \\
\text { Double }\end{array}$ & $.099^{* *}$ & $.050^{* *}$ & $.065^{* *}$ & $.053^{* *}$ & -.033 & $-.078^{* *}$ & $-.104^{* *}$ & $-.041^{*}$ & $-.097^{* *}$ \\
\hline $100 \%$ Double & $-.432^{* *}$ & $-.282^{* *}$ & $-.116^{* *}$ & $.144^{* *}$ & $.207^{* *}$ & $.111^{* *}$ & $.129^{* *}$ & $.143^{* *}$ & $.205^{* *}$ \\
\hline
\end{tabular}

${ }^{*} p<.05 ;{ }^{* *} p<.01$ 
i Table 1 was used to calculate this and, as a consequence of using data source totals, the risk of double counting could not be combated; thus these figures are only indicative.

ii Information could only be obtained for a geographic area, not a specific factor (e.g. loft insulation) across all areas. Therefore Norfolk COA-specific spreadsheets were compiled individually, prior to a master spreadsheet being constructed. The HEEDonline's recent upgrade allows single report downloads for all the COAs in a specific area. 